\title{
A POPULATION STUDY IN SOUTH GUADALCANAL : SOME RESULTS AND IMPLICATIONS
}

\author{
By Murray Chapman*
}

$\mathrm{O}$

$\mathrm{NE}$ of the difficulties Pacific administrators frequently encounter is inadequate basic information upon which to formulate policy. Research workers come and go, yet to tease any applications from their published statements is both a delicate and time-consuming task. From a practical standpoint such results, when ultimately published, also may have dated considerably. ${ }^{1}$ The aim of this paper is, therefore, to present the first results from a village-oriented study of population movement in the British Solomon Islands Protectorate (B.S.I.P.) and to point to some of the implications these have for the administrator. ${ }^{2}$

This enquiry, undertaken between October, I965, and February, I967, focussed upon the reasons for the people's considerable mobility and, more specifically, the interplay of social and economic factors. A detailed investigation was made of a coast and a peripheral bush village (Duidui ${ }^{3}$ and Pichahila respectively) on south coast Guadalcanal, a narrow strip isolated from the north coast by a mountain backbone that reaches its peak at Mount Popomanasiu (7,647 feet). Exposed to strong prevailing winds for nine months out of twelve, drenched by daily showers, and made impassable after a day's rain by swiftly-rising rivers, this locality is aptly known as the Weather Coast ${ }^{4}$ (Fig. I and Plate IA). To the people the seas of the north coast appear " dead" (tasi mate) ; at home on the south coast they become " live" and devilish (tasi mauri).

* Department of Geography, University of Hawaii, and East-West Population Institute, East West Center, Honolulu.

1 See, for example, Rennie's (1962) discussion of the needs of Pacific administrators for urbanization research. 'Dr. D. G. Cochrane, Syracuse University, has in preparation a manuscript, "Human Constraints in Development", that considers the relationship of academics to administrators and is the outcome of two administrative tours in the British Solomon Islands ; see also Cochrane (in press).

2 This paper is the substance of a report volunteered to the Western Pacific High Commission in November, 1967, nine months after my departure from the Protectorate. Its publication ought not be construed as complete or partial agreement with its content, interpretations or suggestions on the part of the Western Pacific High Commission or any individual officer of the administration (see acknowledgements). As with the original version, responsibility for this statement is entirely my own.

${ }^{3}$ The absence of linguistic research for most Guadalcanal dialects makes difficult the spelling of place names and the transliteration of local expressions. Hackman's (I968) guide to the spelling and pronunciation of place names in the Solomons contains a standard orthography that attempts to rationalize the sound variations evident from a preliminary survey of 74 languages and dialects. This system has been approved by the Department of Lands and Surveys for the transliteration of all local place names. It is not, however, phonemically based. 
Within this seemingly inhospitable environment, or one-quarter of Guadalcanal's area, live about $35 \%$ of the island's total population. Estimated in 1965 to number $5,993,{ }^{5}$ the people are nominally Christian (South Sea Evangelical, Roman Catholic, Seventh Day Adventist and Anglican) (Fig. 2), speak eight identified " languages " and, except for the eastern tip around Marau Sound (Fig. I), are grouped in exogamous matrilineal moieties. Yam, taro and kumara are the main root crops grown by these shifting cultivators, and gently sloping valley bottoms may be left bush fallow for up to 20 years when technically ro to I5 would suffice for forest regeneration and soil replenishment (Barrau, I958: 25). As before the war, wage labour is the major source of cash, with copra derived from scattered plantings of coconuts providing a local supplement. The expression heard constantly, "We are a poor people", is at once both stereotype and fact.

Despite the construction of some cutters and two local airstrips (Fig. I), the Weather Coast is still effectively isolated from the economic and political power of the north coast (Plate IB). This, compounded by the population's independence, has led to their substantial sympathy with Moro of Makaruka (Fig. I), a cult leader who aims at both socio-political identity and economic advancement for the Weather Coast as for the whole of Guadalcanal. ${ }^{6}$ Parallel trends are apparent in such villages

\section{(Continued from page 119)}

Duidui, for example, is officially spelt "Nduindui". As said by the people, there is no pre-nasalization of the initial consonant and the degree of pre-nasalization in the middle of the word varies greatly between different speakers. Throughout this paper, as a result, the transliteration of Weather Coast place names departs from the official orthography, as below, and for the remainder of Guadalcanal follows either Hackman's (1968: 15-18) list or a map of Gaudalcanal villages (scale $\mathrm{I}:$ 150,000) completed in March, 1968, by the Departments of Geological Surveys and Lands and Surveys, Honiara.

\begin{tabular}{ccc|c|c}
\hline \multicolumn{1}{c|}{ Sound } & & & $\begin{array}{c}\text { Weather } \\
\text { Coast }\end{array}$ & $\begin{array}{c}\text { Official } \\
\text { Orthography }\end{array}$ \\
\hline Pre-nasalized $\mathrm{b}^{*}$ (as in timber) & $\ldots$ & $\ldots$ & $\mathrm{b}$ & $\mathrm{mb}$ \\
Pre-nasalized d* (as in render) & $\ldots$ & $\ldots$ & $\mathrm{d}$ & $\mathrm{nd}$ \\
Pre-nasalized g* (as in single) & $\ldots$ & $\ldots$ & $\mathrm{ng}$ & $\mathrm{ngg}$ \\
Velar nasal ng (as in singing) & $\ldots$ & $\ldots$ & $\mathrm{n}$ & $\mathrm{ng}$ \\
\hline
\end{tabular}

* Except for an initial consonant.

4 The post-war history and current politico-economic position of the Weather Coast recently has been summarized by Davenport and Çoker (1967: 129-139). More brief or more specialized accounts of the geomorphology have been provided by Grover (1957: 310-312) ; of susceptibility to flash flooding by Grover (I965); of devastation from intermittent cyclones by Sister Veronica (1955); of population change in the early 'fifties by Wrightson (r953); of social organization by Hogbin (1937: 64-69, 1938), Wright (1938) and Allan (1957: 64-65); of language by Capell (1930, 1962: 181-182) and Hackman (1968); of marriage and village economics by Hogbin 1937: 69-77) ; and of potentially commercial copper deposits by Winkler (I968).

${ }_{5}$ This estimate is derived from a head count taken between January and June, I965, by district clerks of the Guadalcanal (local government) Council. Thanks are due to Mr. J. L. O. Tedder, District Commissioner, Central Solomons, for permitting access to the detailed sub-district returns.

${ }^{6}$ The Moro Movement has been meticulously surveyed by Davenport and Coker (1967) and the writing up of a more detailed study, undertaken by Gülbün Çoker O'Connor between November, 1965, and November, 1966, was recently completed (O'Connor, I969). In mid-1964 followers of this movement were estimated to number between three and four thousand adults and about half the area of Guadalcanal was under its hegemony (Davenport and Çoker, 1967: 136-137 and map 2). 
A POPULATION STUDY IN SOUTH GUADALCANAL

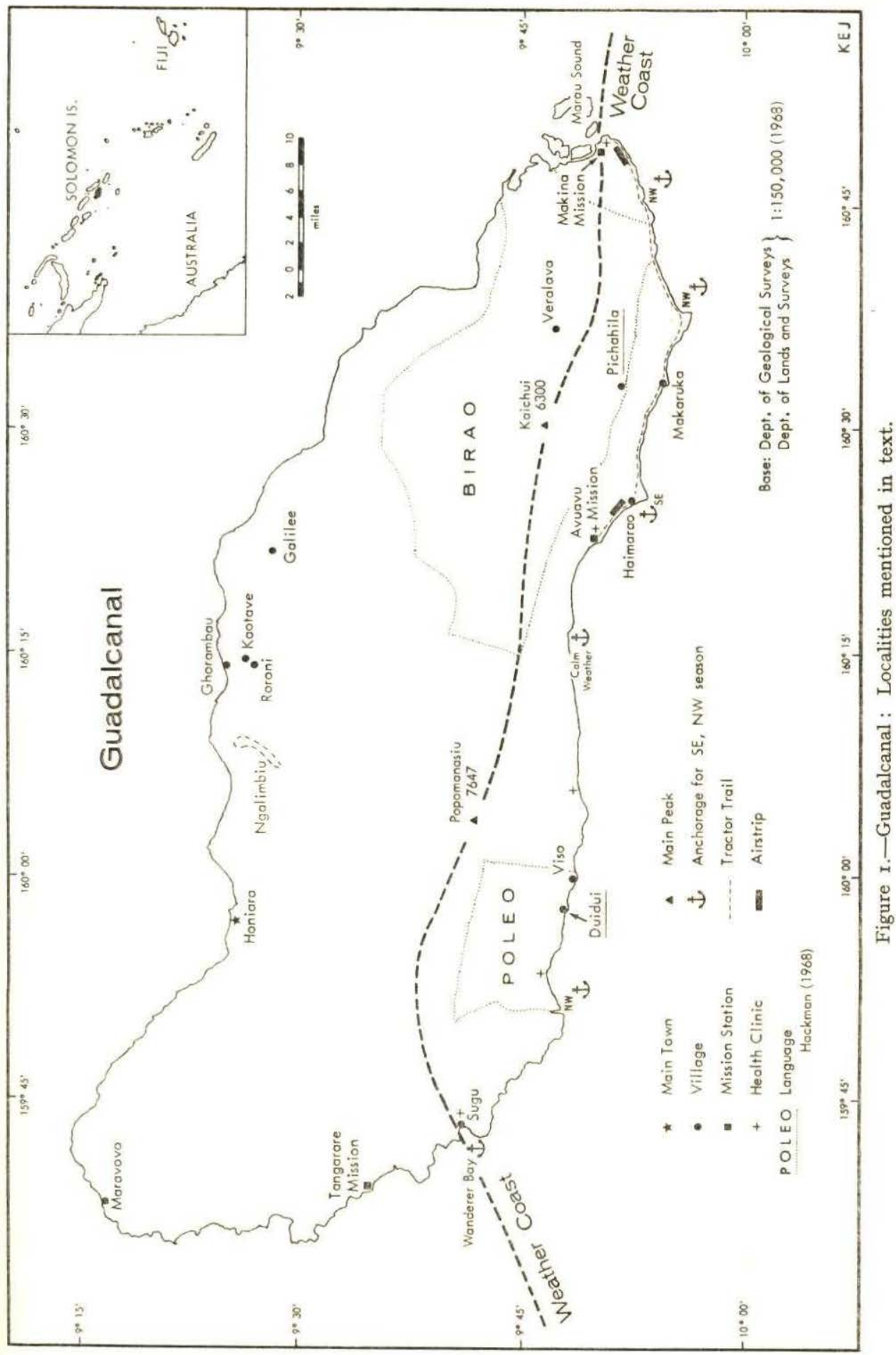




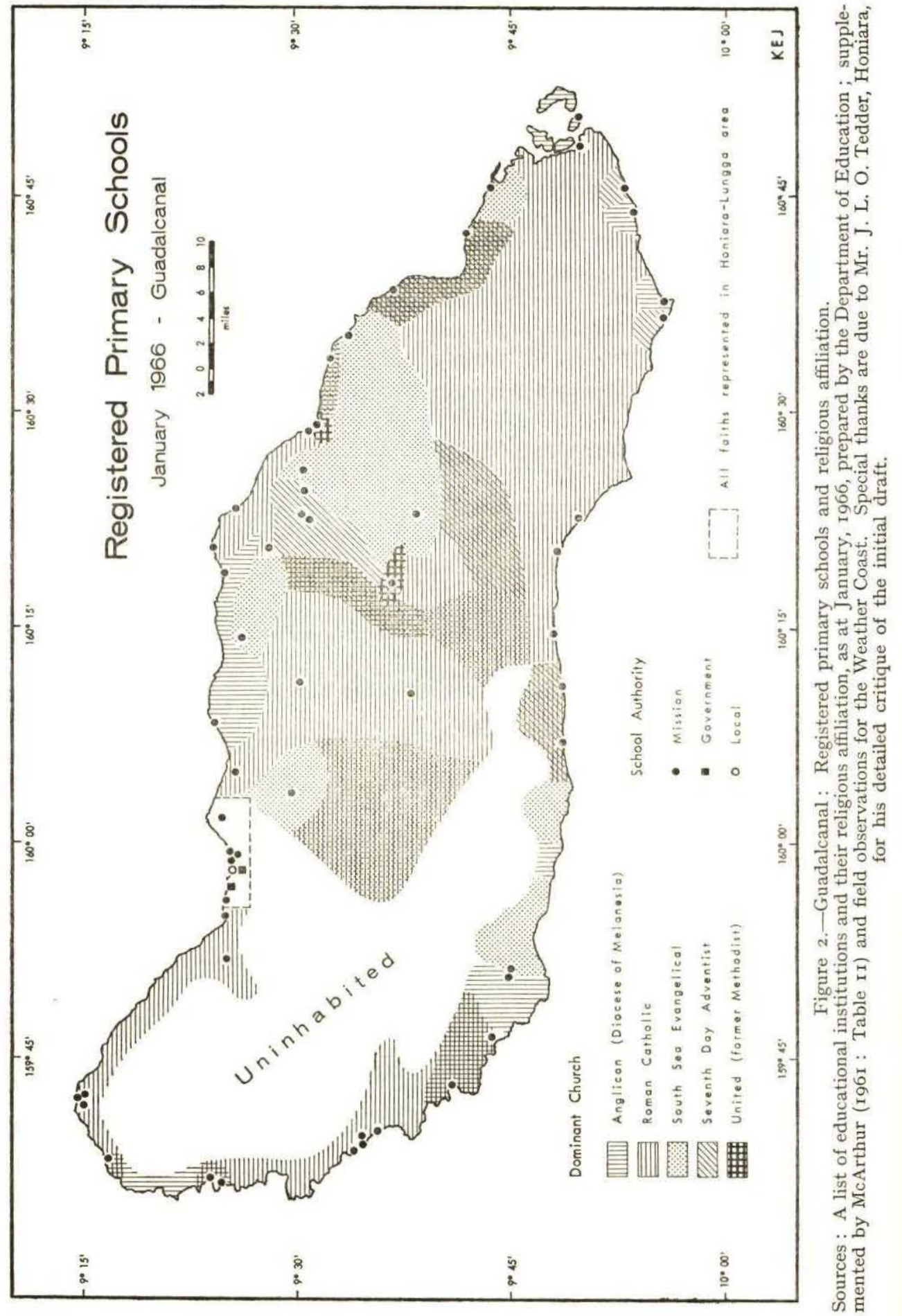


as Duidui, Haimarao and Pichahila (Fig. I) that steadfastly refuse to be part of Moro's efforts, but seek to attain comparable goals through the more conventional means of the district administration and the various missions.

Unless otherwise noted, the statistics for Duidui are the final results of a census taken between I8th January and I7th February, I966, and updated as of Ist March, I966; those for Pichahila refer to Ist October, I966, but the actual enumeration occupied from 22nd August to 26th September, partly because for ten days in late August the village was stricken with a particularly virulent form of influenza. The checking and coding of the mobility register, on the other hand, is still in progress and any figures for population movement are based upon tallies made by an interpreter, with error likely to range from $2 \%$ to $5 \%$.

The household schedule was modified from that used for the Honiara census in October, I965 (B.S.I.P., I965), which in turn elaborated that of the Protectorate-wide sample census taken in I959 (McArthur, I96r: 79). Each villager was asked his name, clan, relationship to head of household, sex, marital status, place of birth, place of residence (if different from that of birth), religion, schooling, money earned in 1965 and at what kind of permanent or sporadic work. Every individual was recorded as present in or absent from the household to which he normally belonged. Women aged 15 or more years were questioned about the number of children ever born to them, age at the date of the first born, and number still living. Each head of household supplied details concerning the number of houses owned (sleeping, cooking, copra, boat, visitors); whether cooking was done in a separate dwelling, a lean-to, or the place slept in ; and the age of the sleeping house, the material composition of its roof, walls, and floor, and whether it was on piles or on the ground.

Unless simple English was specifically requested, interviewing was in the local language through an interpreter trained whilst the schedule was being tested. ${ }^{7}$ All members of a household usually gathered during enumeration, although wives normally left the husbands to answer wherever possible ; this family core frequently was ringed by a fluctuating group of curious onlookers. The time taken per household varied from 40 minutes (for three persons) to two hours ro minutes (for Io persons), ${ }^{8}$ and there were no refusals. Precautions were taken, however, to question the infirm in the presence of the eldest son. ${ }^{9}$

\section{Population Structure of Duidui and Pichahila}

On Ist March, I966, the coast village of Duidui, West Talise (Fig. I) had a de jure population ${ }^{10}$ of 221 residents in 40 households, ${ }^{11}$ or 5.5 persons per household ; on

${ }^{7}$ Since a different language is spoken by the two villages (Fig. $\mathrm{r}$ ), this time-consuming procedure had to be repeated.

${ }^{8}$ Unfortunately the time taken per schedule was recorded only for the second, and bush village (Pichahila), for which the rate of completion tended to be slightly faster.

? Further details of the overall study have been outlined in Chapman (1967), some copies of which are available to interested field workers.

${ }^{10}$ The population "usually present "- the basis of a de jure enumeration-was defined by the people themselves or, in the case of a division of opinion, by a consensus of the relevant 
Ist October, I966, the bush village of Pichahila, Tetekanji, contained IIo persons in I8 households, or 6.I per household (Plate IIA). As the people themselves comment, these are " big villages" by Weather Coast standards ; in I965, only one village $^{12}$ in five was estimated to have more than roo inhabitants (Table I).

TABLE I

Size-Class of Weather Coast Villages, 1965*

\begin{tabular}{|c|c|c|c|c|c|c|}
\hline \multicolumn{6}{|c|}{ Population } & \multirow{2}{*}{$\begin{array}{c}\begin{array}{c}\text { Number } \\
\text { of } \\
\text { Villages }\end{array} \\
\text { I4 }\end{array}$} \\
\hline $0-25$ & $\ldots$ & . & $\ldots$ & $\ldots$ & $\ldots$ & \\
\hline $26-50$ & . & . & $\ldots$ & . & . & I8 \\
\hline $5 I-75$ & .. & . & $\ldots$ & $\ldots$ & $\ldots$ & I 7 \\
\hline $76-100$ & $\ldots$ & . & $\ldots$ & $\ldots$ & $\ldots$ & $I_{4}$ \\
\hline IOI-I 50 & . & . & $\ldots$ & . & . & II \\
\hline $15 \mathrm{I}-200$ & .. & . & $\cdots$ & $\cdots$ & . & 5 \\
\hline \multirow[t]{2}{*}{ 2OI plus } & $\cdots$ & . & $\cdots$ & . & . & 3 \\
\hline & & . & $\ldots$ & .. & . & 82 \\
\hline
\end{tabular}

* For the electoral wards Wanderer Bay, Duidui, Vatukulau, Talise, Avuavu and Moli. On the definition of "village", see footnote I2.

Based upon 1965 Head Count, District Administration, Central Solomons.

The population of both communities is young, with none of the heavy masculinity reported for some eastern islands like Santa Cruz and Utupua (Davenport, I968 : 2I7) ; consequently, there is considerable potential for growth in the immediate future. About half are aged less than I5-Duidui $5 \mathrm{I} \cdot 6 \%$ (II 4$)$, Pichahila $47 \cdot 3 \%$ (52) —and

(Continued from page 123)

household or the senior men in the community. Such differs from the conventional definition in which, as for the 1959 sample census, " usually present " is said to be any person who has resided within the place of enumeration for the previous year or whose absence from that place was not expected to exceed more than one year (McArthur, I96I : 6). The use of the people's concept of " usually present" reflects a deliberate attempt to arrive at local rather than imposed definitions of population characteristics. In practice, no individual who had been absent from Duidui or Pichahila for more than three years was still considered to be a member of the community.

11 The definition of household follows that of the 1959 census : " A family or a group of people who usually eat together" (McArthur, I96I : 8I). Any man who lives in the single men's house (luma) consequently was enumerated as part of the household in which he took at least his main meal. A household thus defined may embrace up to four kinds of dwellings (sleeping, cooking, copra and boat houses) and up to three separate places in which a household member sleeps. To take an extreme example from Duidui : a widow and her daughter live in the cooking house, the eldest son has his own independent sleeping house, and a young teenage son resides in the luma.

12 Despite the apparent precision of Table $\mathrm{I}$, some qualification is necessary since the definition of "village" depends upon the sub-district clerk responsible for the actual return. A strict comparison of the village populations listed in the head counts for I96I and I965 consequently is not possible: the same settlement may be listed under alternative names, adjacent hamlets may be grouped in different ways, and names of previous sites may be assigned to a village that is known currently by yet another. 
almost three-quarters less than 30 -Duidui $72 \cdot 9 \%$ (I6I), Pichahila $7 x \cdot 8 \%(79)^{13}$ (Plate IIв). Such a high proportion of children less than I $_{5}$ is matched in Melanesia only by the more youthful populations reported since I96o for the Solomons, PapuaNew Guinea and West Irian (Table 2). $\cdot^{14}$

This abundance of children, as the people remark, is explained partly by a lower rate of infant mortality through mass medical campaigns, mounted since 1956 by the administration, for the eradication of yaws and malaria. In the recent and unsolicited words of Marcus Pipisi of Duidui, " More people are born about [as a result of] the malaria spraying. Our population are more high ".15 Over the same period there has been, in Pichahila as throughout the Tetekanji bush, a reduced incidence of leprosy. It is further likely that when these medical campaigns began, the population already was becoming progressively healthier and younger as a result of the introduction, in the mid-'fifties, of more regular medical tours to the Weather Coast and increasing attention to non-endemic illnesses.

Out of the two communities, only one woman (Duidui) aged more than 25 has never been married. Age at first marriage for females ranges between 15 and 24, but is more broadly spread for males, as is reflected in the consistently higher proportion of single men in each five-year cohort between I5 $_{5}$ and 29. The almost complete absence of divorced persons conceals the ease of custom divorce ${ }^{16}$ and a high rate of remarriage: the average number of unions in Duidui was $\mathrm{I} \cdot 3$ ( 74 individuals) and in Pichahila I. 5 (46 individuals). Whilst at least one widowed person is to be found in most adult age-groups, with two exceptions for Pichahila these are either women no longer able to bear children or men whose disposition has labelled them tempera-

${ }^{13}$ The notion of precise age is quite alien to non-literate populations : for the people of Duidui and Pichahila time is cyclical and not chronological. The primary method employed to estimate age, to associate births with a list of dated events, follows the pre-war example of social anthropologists in Africa (Charles and Ford, 1938; Fortes, 1954) and the Pacific (Firth, 1955); with varying success, it also has been adopted throughout Melanesia for post-war censuses in the Solomons, Papua-New Guinea and the New Hebrides. Within Duidui and Pichahila, initial estimates were made by reference to an age table for Guadalcanal updated from the r959 census (McArthur, I96I : 92) and supplemented for the Weather Coast by events recorded in district administration files or village diaries. For further discussion, see Chapman (I967: 9-II, I4-I7).

${ }_{14}$ The great range in the size of these populations needs emphasis (Table 2). As McArthur (1966: ro8-r10) demonstrates in a hypothetical example for Papua-New Guinea, the very smallness of village populations greatly inflates the role of chance as a major factor in abnormal age and sex distributions. Throughout this section, as a result, comparisons with DuiduiPichahila and other Melanesian groups are made solely to indicate the broader context within which the Weather Coast results might be viewed.

${ }^{15}$ Letter 7 th January, I969. This intuitive statement about the relationship between malaria eradication and rates of infant mortality has gained recent support from the I967 Live Births Survey initiated by the Medical Department in collaboration with the London School of Tropical Medicine. In non-malarious parts of the Protectorate 469 infants were reported to have been born an estimated two to three years before the birth of a sibling in 1967 . Of these, only I4 had died before that sibling's arrival-or a death rate of 30 per 1,000 . For malarious islands, by contrast, there were 46 deaths out of 524 recorded births over the same period for a death rate of 88 per $\mathrm{r}, \mathrm{OoO}$. Whether the elimination of malaria is responsible for this startling difference cannot be proven until spraying is extended to localities where the disease is still endemic (Macgregor, I968).

${ }_{16}$ One spouse simply informs the other that the marriage is terminated, without necessarily giving any reasons. 


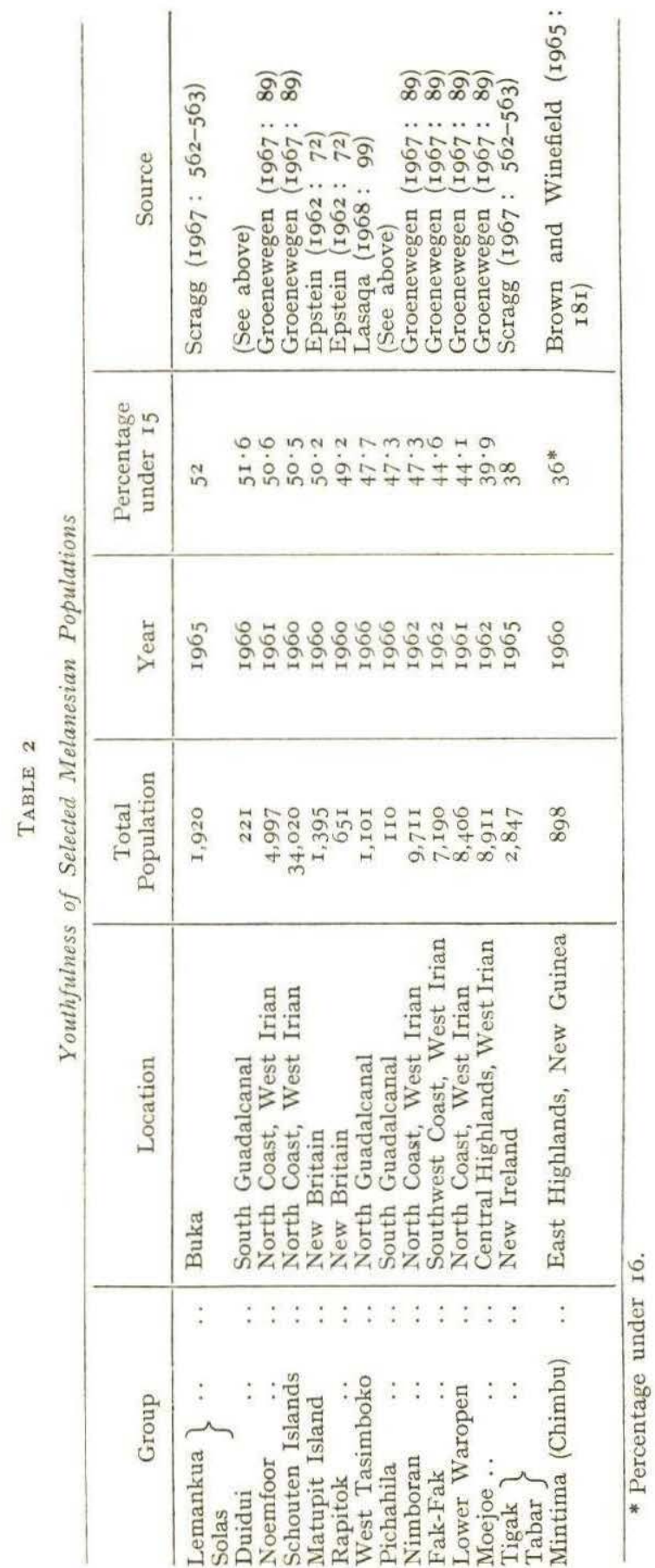


mentally unsuited to marriage. Within the ages 15 to 30 , single men heavily outnumber unmarried women (Duidui 18 : I0 ; Pichahila Io: $\mathrm{I}$ ), but this pattern is largely offset by the fact that residence after marriage is mainly patrilocal and spouses from one's own moiety are forbidden. ${ }^{17}$ These broad patterns of conjugal status, reinforced by the age structure for both villages, suggest that in the immediate future fertility levels will be maintained, or even rise, rather than diminish.

The population is highly mobile. Thirty per cent. were away from both villages at the time of the census (Duidui 46 males, 2I females; Pichahila 2I males, I3 females), with schooling (Duidui 3I; Pichahila 24) and wage labour (Duidui I8; Pichahila 6) the predominant reasons for the absence. Some idea of the magnitude of both long- and short-ternı movements from the standpoint of a local community is provided by a daily register, in which was recorded any individual who either left or stayed in the village for 24 hours or more. This time-span was chosen because it entails an overnight stop and, consequently, a conscious decision ; it also means checking the supply of tobacco, betel nut and lime, taking a change of "calico" [clothing] and, sometimes, even carrying a bed roll. For every entry, information was obtained on the date of the inward and outward shift, the name of the persons involved, their origin or destination, how and with whom the move was made (foot, canoe, ship, airplane), over what time period, and for what reasons (Plate IIIA).

Tallies from this register show the people's ebb and flow to be even greater than expected from the census. December, I965, was an abnormal month in Duidui, for school children journeyed home for their annual holidays, a few men returned from wage labour, and 53 of the I 29 visitors to the special Christmas feast stayed overnight ; nevertheless, a total of 258 moves (I45 inward, II3 outward) experienced by a population of 22I was surprising. ${ }^{18}$ For January, I966, there were II3 such moves (38 inward, 75 outward) as children returned to school and the last of the visitors to their homes.

This volume, though not its structure, was repeated in the bush village of Pichahila where, for July, I966, I35 shifts (74 inward, 6I outward) were recorded; many families left to harvest the new season's yams and live temporarily in their garden houses, five men walked farther inland to hunt wild pig, and the government-appointed Assistant District Headman for Tetekanji (a resident) visited several neighbouring communities. For none of the ten months from December, 1965, to November, I966, during which the register was maintained were less than roo individuals involved. As a result, the week preceding Christmas was the only one in which it was possible to meet practically every member of each community.

17 Although an intensive study of Guadalcanal marriage has never been made, the basic points for the Tetekanji bush have been sketched by Hogbin (1937 : 68-69, 75-76) from information obtained in 1933 during ten days at Tetekanji, now Veralava (Fig. I).

${ }^{18}$ Clearly this is a crude result for it does not distinguish between village members and outsiders. 
The mobility associated with schooling and wage labour is markedly seasonal. Only those Duidui children ( $5_{5}$ in I966) at a junior primary school ${ }^{19}$ six hours' walk to the west, return home during the school year and a few, because of the policy of some missions to hold back pupils over the annual vacation either to look after gardens and buildings or to ensure their continued presence, only once every two years. None of the Pichahila children (23 in I966) visits his parents during the year since Makina (Roman Catholic) Mission (Fig. I), which they attend, is almost a two days' walk. Most of the wage earners do not contract for six to I2 months and, for the two years I965-I966 were absent for varying periods of one to I2 months : an average of six months from Duidui ( 59 men, 7 women) and three from Pichahila (40 men). This annual circulation, mainly of married males aged between 25 and 54 , fits with the planting of yams and taro in August-September and January-February and permits the replacement of leaf on houses during the sunniest months September to March.

\section{Cash Earning and Level of Education}

The considerable number in both villages who, at census date, were at work in the main town of Honiara and on plantations, nearby and distant, European- and locally-owned, was anticipated and the reason for choosing to study the Weather Coast. During I965, Duidui individuals aged eight or more ${ }^{20}$ earned $\$ A_{3}, 836$ and those of Pichahila $\$ A 2,269$ or, per capita, $\$ \mathrm{AI} 7 \cdot 34$ and $\$ \mathrm{~A} 20 \cdot 63^{21}$ respectively. These figures parallel the estimate of between \$AI5 and \$A20 made by Allan (I957: 80) a decade earlier for the Protectorate as a whole, but are substantially less than those collected during 1966 by Lasaqa (I968: Table I2.5) for West Tasimboko: Ghorambau

\footnotetext{
19 Primary education throughout the Solomons, mainly in the hands of the missions, is divided into junior primary (Standards I-IV) and senior primary (Standards V-VII). At the completion of Standard VII, Senior Primary Certificates are awarded to those who pass a Protectorate-wide examination in English and arithmetic. The main secondary school, King George VI in Honiara (Fig. I), is financed by the government but each denomination also maintains at least one of its own in the territory.

20 The definition of "potential cash earner", as those aged eight years and above more accurately reflects the data than the conventional but locally irrelevant one of " work-force" as all persons between 15 and 65 . In Pichahila, four out of 46 with some income during 1965 , and in Duidui three out of 71 , were children less than 15 years old. Especially in the poorer households of Duidui, the receipt of $\mathrm{SA}_{4}$ from the sale of a boy's pig might account for half the family's annual income and pay most of his father's tax. Amongst the elderly, it is not actual age but physical capability and motivation that govern an individual's ability to earn money during any given year. Interestingly, this local definition of " potential cash earner " duplicates the operational one used by several African and Asian countries to enumerate their " economically active population" (Muira, 1967: Table I).

21 Although research on non-literate populations stresses the tedious procedures necessary to estimate age, to obtain the amount of money earned within a stated period was an even more formidable task. These figures probably represent between $90 \%$ and $100 \%$ of all cash earned during 1965, with Duidui closer to the former estimate and Pichahila nearer to the latter. The reluctance and evasion experienced in Duidui during the first week of the census led to a changed strategy that was particularly successful in Pichahila. The general question " Did you earn any money in 1965 ?" was followed by specific ones that enquired about returns from the major local sources of cash (copra, wage labour, pigs, fruit, and vegetables) : amounts were still being entered in the Duidui schedules two months after the actual enumeration had been completed. Only in the last of $I_{4}$ months on the Weather Coast was it volunteered that for individuals to talk about their earnings invited theft and in former times men would be killed for their wealth.
} 
$\$ \mathrm{~A}_{4} \mathrm{I} \cdot 24$, Roroni $\$ \mathrm{~A}_{3} \mathrm{I} \cdot 33$, and Ngalimbiu ${ }^{22} \$ \mathrm{~A}_{27} \cdot 07$ (Fig. I). Such unfavourable comparisons are nothing more than a numerical expression of how the people perceive their economic position - a physical separation from the commercial opportunities of north-west Guadalcanal that is exacerbated by the inefficiency of sporadic shipping to transport perishable but marketable cargoes of citrus, pigs and betel nut to the lucrative market of Honiara. "If we have no transport, it will be very hard for us to get money in market... If we do not produce, our transport [cutter] will have nothing in it. If we have no transport, the produce will go rotten. When we call for others, they will not help us."

The generally higher figures for Pichahila are surprising when viewed against the frequently-heard comment that bush villages have less opportunity to earn cash. Compared with its coastal counterpart, Pichahila has no individually-owned stores, makes no copra, and sells no fruit and vegetables to Honiara. This comparison is misleading, however, since it reflects the sizable earnings of the five permanently employed of Pichahila - an Assistant District Headman, a Marine Department bosun, two technical assistants and a labourer of the Department of Agriculture-who in I 965 accounted for almost half their village's income. If permanent employment as a source of cash is removed from the totals for each community, then the per capita figures are almost identical (Duidui \$Aro.06; Pichahila \$Aro.64) and the average for each wage-earner becomes $\$ \mathrm{~A}_{35} \cdot 85$ for Duidui and $\$ \mathrm{~A}_{28} \cdot 56$ for Pichahila.

For both villages, one-third of all earnings during I 965 came from non-European sources, even though only $14 \%$ (Duidui) and $22 \%$ (Pichahila) was obtained within each. As Lasaqa (I968: 38I-382) reports for the West Tasimboko, most adult males prefer to work for either the Guadalcanal Council or local Solomon Islandersan alternative that has become increasingly possible since the 'sixties with a handful of entrepreneurs to be found in at least every large village. Duidui men concentrate in the coastal strip between Sugu, Wanderer Bay and Maravovo; Pichahila men between Haimarao and the villages of Marau Sound (Fig. I). Within these areas they make copra, brush coconuts, cultivate root crops, build pig fences, and repair or construct leaf dwellings for pay and rations comparable with those offered by nearby European-owned plantations (Plate IIIв). One of the five Pichahila males who earned more than \$Aroo in 1965 went further afield for wage labour to Honiara and two of the nine from Duidui in the same category worked as engineer on a Chinese-owned ship and made copra on a Vella Lavella plantation in the Western Solomons.

The paucity and scattered nature of educational facilities on the Weather Coast means that children must travel long distances to attend a school of their own denomination (Fig. 2 and Plate Iв). Throughout I966 only I5 of the 32 pupils from Duidui remained on the south coast; the others were at boarding school on either

\footnotetext{
${ }^{22}$ Ngalimbiu is the collective name given to the Tasimboko, as distinct from migrants from Malaita, who inhabit ro settlements on either side of the Ngalimbiu River (Lasaqa, 1968: 99, Table 3.1 and Fig. 3.2).
} 
north coast Guadalcanal or Malaita. To this end the parents, near relatives and friends of these 32 pupils outlaid $\$ \mathrm{~A} 475 \cdot 70$ for fees, books, uniforms, clothing, boat fares, cooking utensils and gardening equipment-an expenditure of $\$ \mathrm{AI}_{4} \cdot 87$ per pupil and $12 \cdot 4 \%$ of the village's total income for 1965 . If each of the $5 \mathrm{I}$ children aged between seven and $15^{23}$ had gone to school in 1966 and consumed this average of $\$ \mathrm{AI}_{4} \cdot 87$, then $\$ \mathrm{~A}_{758} \cdot 37$ - or I9.8\% of all earnings in I965-would have been spent on formal education.

The contrast here with Pichahila is instructive, for only one 7-I5-year-old was forced to leave the Weather Coast to continue his (senior primary) education, and the overall expenditure in I966 on fees and clothing for 24 pupils amounted to $\$ A 76 \cdot 80-$ or $\$ \mathrm{~A}_{3} \cdot 20$ per child and a mere $3 \cdot 4 \%$ of the community's income for 1965 . Such a sharp difference highlights the fact that Pichahila is a Catholic village for which, in contrast to Protestant Duidui, classes up to Standard V are locally available at Makina Mission (Fig. I) ; from I965, furthermore, the people of Tetekanji bush have paid fees to this mission on a voluntary basis according to their capacity to accumulate cash. That only two out of 22 Pichahila children aged seven to I $_{5}$ do not attend school is a vivid illustration of what happens when education becomes as nearly free and as nearly compulsory as is yet found in any Solomon Island village.

In Pichahila about a tenth ( 7 out of 80 ), and in Duidui almost one-half ( 76 out of $\mathrm{I}^{8}$ ) of those aged seven or more have had no formal education. ${ }^{24}$ At some time or another $39 \%(62)$ in Duidui and $53 \%(42)$ in Pichahila have attended a junior or senior primary school and not continued on to more advanced secondary or vocational training. Only two out of 49 in Pichahila less than 30 years old, as against $4 \mathrm{I}$ out of 98 in Duidui, have never been to school ; in the latter, furthermore, a higher proportion of the I5-I9 than the IO-I4 age group has received some formal education $(8 \mathrm{I} \%$ to $70 \%)$. Although many Duidui women are reluctant to reprieve their young daughters from garden tasks and have a genuine need for their assistance, this state of affairs reflects less a negative attitude towards education and more the fact that the amount of money earned by each household is rising less dramatically than the number of children who reach school age.

The conflict between a desire for Duidui children to be at school and the cash available to each family is illustrated most vividly in the way an eldest son will attend, but not his brothers or sisters; and by the way relatives band together to pay the expenses of a pupil at a senior primary school. The amount initially required in I966, for instance, to send two boys to Su'u Senior Primary School, Malaita, was

${ }^{23}$ Throughout the Solomons seven is the official age at which children begin school. One of the aims of the 1962 White Paper on Education was to increase the low proportion of seven-yearolds entering Standard I in junior primary schools (B.S.I.P., 1962a: 12).

${ }^{24} \mathrm{By}$ this is meant every type of non-family educational experience from catechist's lessons, in which little more than the alphabet and the numbers I to ro might be learned, to a range of vocational training. "Vocational education" is given its broadest definition to embrace, on the one hand, the on-the-job training of Solomon Islanders who may neither read nor write and, on the other, the year-long programmes of technical schooling sponsored by various government departments and private establishments. 
contributed by ten people. This pattern, given the youth of Duidui's population, is likely to remain the same or become even more pronounced in the immediate future. If the per capita expenditures currently required of Duidui parents do not diminish, then one result could be a reduced proportion of 7-I5-year-olds from the community who attend school —or the reverse of the administration's intent in its White Papers on Education (B.S.I.P., 1962a, 1967).

\section{Kinds of Population Movement}

To the considerable mobility of individuals and family groups for schooling, wage labour and other assorted reasons must be added the relocation of villages revealed by the census question on place of birth. Fifty-two per cent. (II4 out of 22I) of those now resident in Duidui and $64 \%$ (70 out of Iro) of those in Pichahila were born elsewhere. Between one-quarter (Duidui) and one-half (Pichahila) came from inland settlements that no longer exist; thus it underscored the bush origin of these and most Weather Coast inhabitants. Pichahila, established in 1953 through the amalgamation of four " big villages", represents the most coastward settlement of Alualu people since Igoo and probably for all time. In each of Duidui's four hamlets (Duidui, Nalilapina, Vunusa, Isuna) men aged more than 45 can remember at least two inland antecedents to the present site, the first of which was abandoned in I908; in every case the most recent shift has occurred since I945 (Duidui I945; Nalilapina and Vunusa I946; Isuna I96I).

Administration and mission policy to concentrate the people in coastal and near-coastal areas undoubtedly has been influential in this continued relocation of villages. "We moved because [Guadalcanal] Council told us to" (Pichahila); "Government and missionaries invite us to come" (Duidui) ; " [The Guadalcanal] Council told the people who live in small villages to come and live in a big village " (Pichahila). Other frequent reasons are natural hazards such as the I93I earthquake and the recurrent flooding of some sites; idiosyncratic incidents like the burning of several dwellings by a teenage girl ; and, for earlier shifts, the continual fighting between antagonistic bush communities. Although the frequency of village shifts has slowed since World War II, the people refer to it as "our custom way " and do not rule out the possibility of further transfers. In some cases, and particularly in Pichahila, the adults are weary of their continual wandering ; in others, the older men realize that the planting of coconuts, the establishment of stores and the lack of land not put to some minimal use has reduced the possibility of future shifts. The relocation of settlements is, nevertheless, so much a part of their past that a concerted effort by a forceful personality, such as an autocratic "big man " or a misguided administration or church official, still could cause a Weather Coast community to move, or at least to break up and be absorbed into others nearby.

Observers like Allan (I957 : II7) have commented upon the residential stability of the Solomon Islander. If by stability is meant how firmly rooted is he to his home village, wherever it might be located, then this is clearly correct. But given this tie 
to their own community, the people of both Duidui and Pichahila are in fact far more mobile than the stereotype of tribal society would have us believe. The materials gathered over I6 months suggest three basically different kinds of population movement which, tentatively, are :

(I) Shifts in village locations, generally though not inevitably in a bush to coastward direction : a customary practice in response to natural hazards, epidemics, land exhaustion, warfare and sorcery that, since about I9oo, has been reinforced by administration and mission efforts to consolidate settlement on the coasts or in the river valleys (Plate IVA).

(2) Moves by younger adult males of at least ten days' duration, but seldom for more than one year : to earn money in the main town, at district centres, on European-owned plantations, or from Solomon Island entrepreneurs; to visit Honiara, district and mission stations for retail, educational, medical, and administrative services; to leave for other villages to marry, go to school, or because of a serious dispute (Plates Iв and IVB).

(3) Short-term, mainly familial moves of a highly spontaneous nature, usually for less than five days: to "go walkabout" to other villages and visit kinsfolk, discuss clan and church business, attend a feast ; to live temporarily in the garden house ; to hunt wild pig or trap fish ; to quit the community briefly out of shame or by way of protest (Plate IIIA). This kind of mobility rarely penetrates the language boundary: Poleo (Duidui) and Birao (Pichahila) (Fig. I).

Once known, these broad patterns cleally could assist the administrator in formulating and siting community development schemes, in locating extension or social services, in disseminating information, and in scheduling important or prolonged district tours. They also are relevant to the stability of labour, programmes of vocational training and the quality of education from the village's standpointand it is with these larger questions that the second part of this paper is concerned.

\section{Mobility AND LABOUR TURNOVER}

The continual circulation of Solomon Islanders between their home community and other villages, mission stations, plantations, district centres and Honiara impinges upon many aspects of local life and, therefore, of Protectorate administration. At the time of the I959 census, the de facto population ${ }^{25}$ of Honiara totalled 3,534 (Tedder, I966: 37) ; by October, I965, it had risen to 6,684 (B.S.I.P. News Sheet, ${ }^{26}$ I966/I : 4); late in I968 it was estimated at 8,500 (Hughes, I969: I9). One of the interpretations frequently drawn from such figures is that more and more Solomon Islanders are becoming permanent urban dwellers, a view echoed in a recent survey of low-cost housing that speaks of "the growing readiness of Solomon Islanders

${ }^{25}$ The population actually present at a particular moment in time, in contrast to de jure population (see footnote ro).

${ }^{26}$ Hereafter referred to as B.S.I.P.N. 
themselves to live in Honiara and make the town their own " (Hughes, I969: 26). The evidence from Duidui and Pichahila, on the contrary, suggests that a distinct increase in the proportion of people, particularly women, who oscillate between the village and Honiara has not been accompanied by a parallel rise in those who see it as their permanent domicile. This is, from the standpoint of the village, simply a reinforcement of Bellam's (I963 : 99, I49) finding when, in I962, only one out of I20 Melanesian males employed in Honiara stated he would remain upon retirement; significantly, this solitary individual was a skilled worker from the more acculturated Western Solomons.

The area administered by the Honiara Town Council consequently contains a highly transient Solomon Island population, the size of which is rapidly expanding but the composition of which constantly fluctuates. Although no figures are available, the increased rate of visiting probably means that in general the Solomon Island component of Honiara's population is to-day less stable than it was five years ago. Of this there are recent manifestations. About 300 squatters who in 1967 had encamped on the town's periphery (B.S.I.P.N., I $967 / 20: 5$ ) had so increased a year later that the Town Council announced its determination to eradicate this practice (B.S.I.P.N., I968/19: 2). At the July, I967, meeting of the Legislative Council, the Honourable Gordon Siama (North-western Solomons) was sufficiently disturbed by " people who have left their homes and stay in the towns for four to six months" to propose that the administration " should investigate the movement of people from the rural areas into the urban areas because many of the persons concerned do not have, or are unable to obtain, employment and are dependent for support upon relations or friends" (B.S.I.P. Legislative Council Debates, ${ }^{27}$ I967/I: 345). The Secretary for Protectorate Affairs, the Honourable R. Davies, in acknowledging both the existence and complexity of the problem, thought one possible remedy would be for the administration to examine " its rural development programmes to see whether they can be made attractive enough to dissuade some of the people from drifting away from their villages merely for want of anything better to do " (ibid., 347).

Probably not more than Io in I,O0o who are gainfully employed in Honiara wish to remain permanently, and even the most highly-qualified civil servants intend to retire at least to their own island. This recurrent pattern is reflected in a recent news item: "Leading Telephone Linesman James Kaukau has just retired after nearly I7 years of Government service. He . . will return to his home on [Santa] Isabel " (B.S.I.P.N., I968/I-2: I4). Anyone who irrevocably renounces his village is analogous to a displaced person in Euro-American society ${ }^{28}$; in the words of a

$\mathbf{2 7}$ Hereafter referred to as L.C.D.

${ }^{28}$ The most unexpected support for this interpretation comes from a lively meeting held in April, 1966, at the British Solomons Training College. Not one of about 50 men and women, all Solomon Islanders from each of the four administration districts, was prepared to live and work in Honiara upon completion of their teacher training. When pressed, a handful conceded they would work away from their home island but all were adamant the long-term goal was to help their local communities. They were less articulate, and sometimes ambivalent, about the reasons for their distaste for Honiara, but the absence of their own land and any feeling of identification with the town seemed uppermost. 
favourite pidgin English expression, "Passport bilong him lose finish. Him now, i no savvy go back long village bilong him " [He lost his passport so that he could not go back to his own village].

In this sense residential attitudes to-day are no different from those elicited in I958 during a comprehensive but largely ignored investigation into the housing of Solomon Islanders in Honiara (Russell, I958 : I4). For the villager who has no special skills or formal education to sell, one to two years' continuous stay is a long one ; seven months was the average for the I 9 men and three women from both Duidui and Pichahila who, during 1965-1966, worked in the main town for one or more months. ${ }^{29}$ Port towns in the Pacific are renowned for the fluctuating composition of their populations (de Bruijn, I963; Belshaw, 1963), but that of Honiara is even more highly transient than most.

This considerable mobility raises the question whether Solomon Islanders, as the overwhelming source of labour throughout the Protectorate, can be stabilized to some extent not only in the main town and district centres but also at any place of employment. The answer fortunately does not lie in some legislative measure to either prohibit or regularize freedom of movement within the territory. Until I964, when Section 64 of the Native Administration Ordinance was repealed, no person was permitted to leave his sub-district for more than seven days without the Headman's permission (L.C.D., I964/I : 3I). In practice Headmen could only refuse approval for some special reason, District Commissioners had the power of veto, and this Section was seldom invoked (Tedder, I967). As the Honourable Mariano Kelesi (North-east Malaita) once declared during a Legislative Council debate: "I should be very reluctant to approve any law to prohibit any person from moving about [the Solomon Islands] " (L.C.D., 1967/1 : 346).

At the crux of this life-style are the basic reasons for the Solomon Islander's constant ebb and flow: the largely polarized distribution of a village-dwelling population on the one hand and the prevailing sources of employment on the other ; the people's need to earn cash not only to pay their local taxes and school fees but also to obtain some of the material items of a money economy ; and the fact that housing at most work places is available for men, without women or children (Plate IVB). This problem consequently resolves itself into one of the type and quality of housing offered to Solomon Islanders who, to acquire money, must live away from their homes for months at a time.

If, for instance, an oversea company found it economic to mine the nickel deposits recently assessed on San Jorge Island, off Santa Isabel, and established a model village, then undoubtedly it would attract entire families in addition to the normal complement of young married and unmarried individuals. Although the women would prefer to stay at home, every year they see a high proportion of the able-bodied men journey somewhere to work. Many of them, as a result, could be persuaded to

${ }^{29}$ The 1965 annual report of the Labour Department (B.S.I.P., r966b:9) notes this to be a feature of the whole Protectorate. 
accompany their husbands at least some of the time and provided that some facilities for family living were made available. In the words of Miss Lily Ogatina, a former member of the Legislative Council,

They [the women] would rather be back home. But, as a whole, the husband is always the master. If the master says: "We'll go ", they have to go. And if the master says: "Oh well, I suppose you've got to stay back and look after what we've got at home", she'll have to stay at home.

And again in the same interview: "If these people are going to be encouraged to work in urban areas... housing should be made available so that their families could come with their husbands to work " (Solomon Islands Broadcasting Service, ${ }^{\mathbf{3 0}}$ I966).

One illustration from Pichahila will suffice. An energetic and ambitious young man about 30 years of age departed for Honiara in January, I966. From June he was employed by a government department, but when in November he announced his intention to leave for home, his supervisor was reluctant to see him go. It was suggested that he return early in the new year, accompanied by his wife and child, and reside in married quarters. When informed of this prospect, very soon after her husband's arrival back in Pichahila, his wife declared she was "willing, because I want to look at Honiara ". Within eight days, a letter had been written to the former supervisor and received a speedy reply: there were no married quarters available but a leaf house could be built on some garden land on the town's periphery. At this news the former wage-earner lost interest.

The lesson is clear. If employers throughout the territory were to offer housing for families, the wives-and particularly the younger and frequently more sophisticated-would be willing to accompany their husbands to most work places at least within their own island. In such a case the family would padlock its house, leave its pigs in the care of close relatives, possibly even transfer the use of its garden land. More crucial, there would be a greater willingness to stay away for what, to a family, is a considerable length of time: say, two to three years. Although this absence would not imply permanent rejection of the village, from the standpoint of the employer it would make for a more stable work force and therefore help reduce the high rate of labour mobility found throughout the Protectorate. "If they [employers] try to attract men, unskilled labour to become semi-skilled ", the Honourable Mariano Kelesi once volunteered during a panel discussion, "I think the whole idea is to build them houses ... then you have a continuity of labour that will cheapen the repatriation and recruiting of labour" (S.I.B.S., I966).

Such a suggestion is foreshadowed in the methods evolved by various private employers. One planter in the Western Solomons, for instance, has encouraged men to bring their families, established a school for children, and provided a pension fund for long-term stayers ; in addition to a paid holiday each year, the predilection of

${ }^{80}$ Hereafter referred to as S.I.B.S. 
wage-earners to "go walkabout" is recognized in the provision for one month's absence without pay upon request. As a result of these incentives special recruiting efforts are no longer necessary and some married workers who have been employed continuously for 15 years recently asked that they be granted permanent household sites (Scott-Elliot, I967). The low-cost housing and home ownership scheme in Honiara, ${ }^{31}$ initiated by the administration and subsequently adopted by several commercial firms, reflects a similar philosophy. The construction during I968 of I56 family dwellings (B.S.I.P.N., I968/23: 3), estimated to accommodate 780 Solomon Islanders, was confined primarily to three town localities to help stimulate the development of close-knit, village-type communities. After years of relative inertia, this scheme dramatically implemented the official policy to encourage wherever possible " the establishment of a higher proportion of married workers at places of employment" (Wilmot, I967).

Without careful implementation, however, such programmes could have an unnecessarily negative impact upon village society. The local community can and does adjust to the loss of its able-bodied men for periods of less than one year. When, in the first three months of 1966 , I8 out of $4 \mathrm{I}$ males aged between $2 \mathrm{I}$ and 54 left Duidui for wage labour, the three- to six-year-olds, the elderly and the infirm were utilized more and more to carry water, prepare vegetables, nurse infants, and keep the village swept and weeded. This same adjustment also has been observed for the north coast Tasimboko, for whom "sojourn at places of work does not necessarily cause excessive strains in the functioning of the village. Men who go away unaccompanied on paid work for brief periods can and do make arrangements for the welfare of their families. Their cash remittances are often used to hire labour which will ensure the performance of essential services" (Lasaqa, I968: 38I-382).

A point can be reached, on the other hand, where the number of families who accompanied their menfolk would be too great to permit a community to function. That Solomon Islanders recognize such a possibility is underscored by reservations voiced by some Legislative Council members about the Honiara low-cost housing scheme. At the June, Ig68, meeting the Honourable Mariano Kelesi, whilst initially praising the scheme, startled government members with his complaint that the dwellings were cheap, their sites poor, and the whole atmosphere morally depressing. This scheme, he emphasized, was " a clear indication of class discrimination" (B.S.I.P.N., I968/II: 9). Less contentious statements were made in December by Mr. Willie Betu (Isabel-Russells) and Dr. Clement Ofai (North Malaita). Home ownership in Honiara, Mr. Betu warned, meant that families would "lose contact with their own people and their children would grow up as town children " ; Dr. Ofai advised home owners to consider that "town children had no guarantee of an

$\mathbf{3 1}$ This scheme has been succinctly reviewed by Hughes (1969). More details of the substantial progress made throughout 1968 are contained in successive issues of the fortnightly B.S.I.P. News Sheet. 
education or a job; ... very likely ... a number of these children would get into trouble "32 (B.S.I.P.N., I968/23: 4).

The clear concern was that over time the village could become, through home ownership in Honiara, just as through more families accompanying their men to work, a refuge for the young and the old: the former to await the day when they could leave for school, the latter to hold tightly to their past and look forward to a lonely death. Such a belief is not tempered by the fact that Sections 36 and 37 of the Labour Ordinance (Cap. 28) exist to guard against the unnecessary depletion of a village's work force ${ }^{33}$; or that local government councils have the power to propose, if they wish, by-laws about the proportion of families who may be absent from a village at any one time (B.S.I.P., I962b) ; or even that most communities have their own methods of monitoring the number of able-bodied residents permitted to leave for wage labour. ${ }^{34}$

As an address by the Roman Catholic Bishop of Honiara indicates, the people's constant circulation is accepted by the younger age groups. Young men in training at Tangarare Mission (Fig. I), Bishop Daniel Stuyvenburg declared, "should not think only of going to the towns " and what they learned in carpentry and cropping would help them improve the local community (B.S.I.P.N., I967/18: 6). Alongside this must be placed the fact that, as already noted, Duidui and Pichahila males prefer to be employed by either some village entrepreneur or the Guadalcanal Council. More local sources of cash would not, however, necessarily eliminate or even reduce their mobility. The evidence on this point is fragmentary and relates only to the coastal community ; nevertheless, five out of I4 household heads stated they would continue to visit Honiara and other places even if they could earn a satisfactory income amongst their own people. Said one of the more senior Duidui men : "I do not like to stay in the village all the time."

The problem of a less mobile work force is complex but, given the prevailing patterns, not incapable of solution. What is crucial is that the provision of married quarters as a desirable means to increase labour stability implies a more delicatelybalanced policy towards the village than some employers and administrators at present seem willing to admit. ${ }^{35}$

32 At time of writing the Official Report of the 1968 Legislative Council Debates was not available. The above statements consequently have been abstracted from the B.S.I.P. News Sheet which, it requires emphasis, presents a selective summary rather than a verbatim account of Legislative Council proceedings.

${ }^{33} \mathrm{I}$ am indebted to Mr. B. C. Wilmot, Commissioner of Labour, for pointing this out.

${ }^{34}$ When, for instance, the number of resident able-bodied males reaches a certain point in some Polynesian outliers like Sikaiana, the remaining men are strongly pressured not to leave until some of the absentees return (Wright, I969). In I964, two Tikopia chiefs stated that no more than 30 to 40 men with their families should depart at any one time for Lever's Plantations in the Russell Islands (Larson, I968: I66).

${ }^{35}$ How little Europeans know about the ways in which Solomon Islanders view their present socio-political position is illustrated by the reception accorded Bugotu's (r968) paper, "The Impact of Western Culture on Solomon Islands Society "', given in May, 1967, to the Second Waigani Seminar at the University of Papua-New Guinea. Although locally held to be a provocative and at times slightly bitter statement, it has been republished in B.S.I.P. News Sheet, Melanesian Messenger, New Guinea and, most recently, South Pacific Bulletin. 


\section{Seasonal Movements and Vocational Training}

Even if labour turnover is not able to be reduced in the immediate future, its distinctly seasonal character suggests modifications to existing programmes of vocational training that may help to achieve the same result. The employer, on the one hand, depends upon the village for his supply of manpower ; on the other, few married males are prepared to remain continuously at work because August to February are particularly busy months during which new gardens must be cleared, root crops harvested and planted, leaf dwellings built or repaired. Especially in Honiara, the employer therefore does not feel inclined to put any distinct effort into the training of even minimal skills when they are lost to him the moment the villager quits his job to return home-frequently never to be seen again.

This seasonal availability points to a compromise beneficial to both parties, provided that the employer adopts a long-term view. On-the-job training could begin the moment a man was hired for the period February to August. This should not be regarded as largely wasted time but rather a trial period that might lead to an annual, but six months' long association between employer and wage-earner. At the end of such a trial period both parties could, if mutually satisfied, come to an arrangement whereby the Solomon Islander guaranteed his labour the next year in return for family housing and subsequent training in more difficult tasks. Were such to occur for three to seven years, the cumulative experience and on-the-job training would about equal the non-apprenticeship programmes currently available in Honiara for many of the manual trades (B.S.I.P., I966a). Clearly such a scheme would not be feasible in the more highly-skilled trades nor in the courses envisaged for the Technical Training Institute currently being established. It would, however, be applicable to the training of painters, carpenters, plasterers, bricklayers, plumbers, linesmen, electricians and mechanics. Given the inexperience of previously unemployed labour, for these and other tasks on-the-job instruction could be in pidgin English, since written or spoken English would not be a basic necessity.

The strategy proposed is not, it needs emphasis, an indenture system in unfamiliar guise or a reversal of administration policy to eliminate written contracts of service ${ }^{36}$ As envisaged, the arrangement between employer and wage-earner would be verbal and based upon mutual understanding, with the latter losing an assured job and family housing should he not return the following year within a specified period of, say, one month. Obviously employers would only be interested in an annual, six-months-long association with individuals judged to be energetic, trustworthy and manually dexterous ; Solomon Islanders would be similarly unwilling unless especially impressed by the treatment received during the initial period of employment and during what, to them, would have been " just another job ". Such a procedure initially might appeal most to smaller employers whose scale of operation

\footnotetext{
36 In the original report to the Western Pacific High Commission this suggestion was termed an "agreement" - a word that revived memories of written contracts and systems of indenture, Special thanks are due to Dr. A. M. Healy, Wollongong University College, and Mr. B. C. Wilmot, Commissioner of Labour, for forcing me to clarify the presentation.
} 
inevitably means closer and more individualistic contact with their employees. Like the settlement for Tikopians on Russell Islands that has provided Lever's Plantations with a more stable and productive work force (Larson, I968), the aim is to adapt conventional employment practices to local behaviour patterns.

In this way programmes of vocational training could be evolved to mesh with the markedly seasonal flow of labour. The employer would have an assured, if discontinuously-available work force that gradually would become more and more skilled; for the Solomon Islander it would mean a guaranteed job to which each year he could take his family, yet still be able to function as a member of village society. Thus could labour to some extent become stabilized and thus could simple manual skills percolate to the local community at a far greater rate than now occurs.

\section{Non-Village Schooling and Educational Quality}

Throughout the Solomons relatively few schools, like the sources of wage employment, are located within the village. Most children therefore attend boarding school, but the distances they travel and the time they are absent frequently are increased because the classrooms nearest to their home are not controlled by their own faith or lie outside their "school district". Thus Pichahila pupils must walk two days east to Makina (Roman Catholic) Mission when they are only six hours west of Avuavu Mission; thus Duidui children whose parents are South Sea Evangelicals cannot be educated beyond Standard III anywhere on the Weather Coast and must go to either Kaotave or the island of Malaita (Plate Ів) ; thus Duidui girls baptized in the Diocese of Melanesia were unable, between I965 and I967, to find schooling within two days' walk and those who had already reached Standard III were forced to journey by local cutters to Galilee-or that part of north coast Guadalcanal that is virtually farthest distant from their own village (compare Figs. I and 2).

John P. Hoka, a member of the Legislative Council, once observed on Rennell and Bellona that " religious differences should not prevent children attending a school of another denomination" (B.S.I.P.N., I $967 / 17$ : 5). The parents of both Duidui and Pichahila would agree with this philosophy only if an institution were obviously non-denominational and therefore the responsibility of either the Guadalcanal Council or some local Weather Coast authority. In fact, $\mathrm{I} 4$ out of the 82 persons from Duidui who have had some formal education owe this to the existence, from 1959 to 1963 , of a Guadalcanal Council school at nearby Malisa and, during 1964, to their own village school.

This paucity of local schools, compounded by the fees and ancillary charges levied by distant institutions, several times has led the people of Duidui and nearby villages to establish their own. The latest and hopefully most successful attempt, directed by District Headman Marcus Pipisi, began in mid-rg66 with the knowledge and quiet encouragement of the district administration. This school, located at Viso 
(Fig. I), aims to be non-denominational and is the co-operative venture of seven villages with a combined population, in 1965 , of about $7355^{37}$ Commented Marcus : "Schooling is one thing, religion another." From December, I966, each village was responsible for constructing at least one leaf building, in the hope that by February or March, 1967 , the school would be open to Standards I to III. A parents' committee drawn from six villages fixed annual fees at $\$ \mathrm{~A}_{3}$ to help purchase equipment. The two to three teachers required for an expected 6o to go pupils were, if unregistered, to be paid from funds granted annually by the Guadalcanal Council to the South Sea Evangelical Mission, to which many of the organizers belonged.

As with many local projects, implementation was considerably more difficult than anticipated and the Viso school did not begin classes until May, Ig68 (C.D.N., I968/5: 4). By then, not only the South Sea Evangelical Mission but also the Diocese of Melanesia and the Guadalcanal Council had become involved. The people's determination, at least indirectly, had focussed attention upon their educational plight and a subsequent survey of the Weather Coast led the Director of Education, Mr. D. H. Hibbert, to declare it " underschooled even by local standards" (Hibbert, I968).

This sequence graphically illustrates the conflict between the parents' desire for their children to be educated and the distances they must travel from their homes to achieve this. It reflects their considerable displeasure that the seven-to-nineyear-olds, in particular, cannot attend school either in or near the home village and, in the absence of any perceptible action from outside authorities, the lengths to which they will go to alleviate such a situation. In the exasperated words of one man : "Always like the British. Always talk and nothing happens." The voluntary construction of Viso school also illuminates a crucial paradox : the people's willingness to supply their land, labour and building materials is handicapped by their inexperience in maintaining a viable institution, in purchasing classroom equipment, and in recruiting and retaining teachers. ${ }^{38}$ This indicates that local ventures might be assisted and encouraged more actively, especially in areas where the ratio of schools to population is low ; in theory, this ought to be facilitated by the 1967 White Paper on Education that vested the responsibility for primary education with the various

\footnotetext{
37 Based upon the 1965 head count briefly described in footnote 5 .

${ }^{38}$ Efforts centred upon the village of Makaruka (Fig. I) provide another example. As part of its activities the Moro Movement established, in 1964, a school to teach English composition and arithmetic to adults. Some success was achieved with this concentrated programme but it was not repeated the next year because the trained teacher, a local inhabitant, subsequently left to accept another position (Davenport and Coker, I967: 166-167). Late in 1966 the district administration, at the urging of the social anthropologist Gülbün Coker, began an experimental adult education project directed by VSOs John Lowen and John Proctor. Their efforts confirmed the people's conspicuous interest in the outside world and their willingness to learn simple English, arithmetic, history and geography (Lowen, I967a, 1967b; Proctor, 1967a, 1967b). Under the sponsorship of the Roman Catholic Church, a junior primary school was finally established in 1968 , with 72 pupils from four villages enrolled in two classes of Standard I (C.D.N., 1968/3: 2; The Forum, 1968/2: 12).
} 
churches and local authorities, ${ }^{39}$ and included subsidies for equipment, trained teachers and the construction of single classrooms. As a news item aptly conveys, the people's enduring conviction is that in formal education lies their hope for the future :

Twenty-seven villagers ranging in ages from 16 to 25 recently attended a Central District Education Office course on the Guadalcanal Weather Coast on decimal currency, reading and writing simple English. The course over two days was held at Makaruka at the request of village leaders, and a longer course has been requested for later this year or in I970 (B.S.I.P.N., I969/9: 8).

The annual return home of pupils for their holidays has a further implication. The presence around Christmas of so many children, each of whom has changed however slightly during the preceding year, is dramatic evidence to both the local community and the individual parent of the kind of education they have receivedand the onlookers' view is all the sharper because of the prolonged period the children have been away and their much briefer vacation of four to six weeks. Often, and particularly in Duidui, the older adolescents were said not to know how to work properly, to be lazy, and to want only to play. Intermittent comments were made about a particular pupil not learning well and how it would be wasted money for him to continue. As the length of time away increased, the children tended to become scornful of many village activities: an attitude that may have been less evident had they been attending less distant institutions on a daily or weekly basis. More regular contacts with their homes would enable the continuing acquisition of local skills along with more academic information; it would also considerably alleviate the boredom observed, particularly amongst older adolescents, upon their return from school.

Since the Protectorate-wide curriculum places heavy emphasis upon English and arithmetic, the children's most obvious accomplishment was simple English. The more advanced were constantly requested to translate letters received from absent kinsmen, the administration or the missions into the local language. For the most part, however, it was not their knowledge of English that was most impressive but its marginal utility within the village and how pupils with fewer than four years' schooling preferred pidgin English in conversation with outsiders. The materials distributed free from the district administration and the information service frequently never travelled beyond the headman's house; the arrival of our mail always attracted considerable interest and young adults with little English often came and sat for two hours to thumb through illustrated magazines. The more advanced or former pupils, no matter how great their actual command of English, were thus functionally illiterate whilst at home through lack of reading materials. This fact is vividly reflected in the number of field workers who, like myself, have been astonished to receive letters in simple English from someone they did not realize could even write.

${ }^{39}$ For example, local government councils, plantation companies, and community organizations like the Chinese Association in Honiara. 
Such a situation is not, of course, any argument against the teaching of English, but it does stress the urgent need for more collections of Solomon Island stories ${ }^{40}$ so that classroom materials are not so divorced from the home environment as to appear ludicrous to both parent and pupil. Widespread instruction during I967 and r968 in the Tate method of teaching oral English was an initial step in the right direction, but more energetic efforts later became possible through the appointment of a full-time Schools' Broadcasting Officer and the generous gift of 595 radios from the Foundation for the Peoples of the South Pacific (B.S.I.P.N. I968/I3-I4: II). School broadcasts at the beginning of 1969 had risen to four and a half hours each day, with the emphasis upon English-language teaching by example from the local environment (B.S.I.P.N., I969/I : 9).

The considerable focus upon English does, however, have its negative aspects, for it reflects a curriculum that, whilst attuned to the needs of Euro-American society, is frequently not relevant to those of a tribal society. "There is a real danger", wrote Father D. J. Moore, S.M., for 20 years Director of Education of the Marist Mission, " in the tendency to give to Solomon Island children a form of teaching and training which is exclusively designed for another country, and oriented towards a form of social and economic existence which tends to estrange them from their traditional rural village life" (Moore, rg65: 38). It is little wonder that parents sometimes remark schooling is " not much good", since the skills that children might learn to help improve their local community are predominantly not those with which they return : for the girls, simple nutrition and hygiene, first-aid, sewing, gardening methods, and handicrafts ; for the boys, crop improvement, carpentry, carving, how to keep simple accounts, how to fashion tin or metal and mix cement. The syllabus for junior primary schools, recently revised but still provisional, introduces rural science to embrace gardening, animal husbandry and village economics, and prescribes a social studies that draws its inspiration from the home environment. It is problematic what kind of improvements are feasible, however, when no more than one-fifth of each week's suggested timetable is allocated to these and more practically oriented subjects (B.S.I.P., n.d. [? r968]).

That a number of children do return home with some simple skills reflects more the interest of individual teachers or outside organizations than the content of a centrally-imposed curriculum. In I968 Sister Mary Noela, who previously had attended a course in commercial sewing at the East-West Center, Honolulu, instituted classes in sewing, cooking and health care at Avuavu Mission (Fig. I) as part of the activities of a women's club. A furniture workshop established by one Roman Catholic mission in the Eastern Solomons provides both a local source of revenue and vocational training for its schoolboy assistants (B.S.I.P.N., r968/I2 : 9). Early in

\footnotetext{
${ }^{40}$ Only two short collections (B.S.I.P., I960, n.d.) are widely available, and these were printed when the Literature Production Training Centre of the South Pacific Commission was located in Honiara between 1960 and 1963. Partly to fill this gap a former District Education Officer (Malaita), Mr. Ian Searle, has written accounts of everyday life throughout the Solomons as the text for a series of English comprehension exercises (B.S.I.P.N., 1968/6: 6).
} 


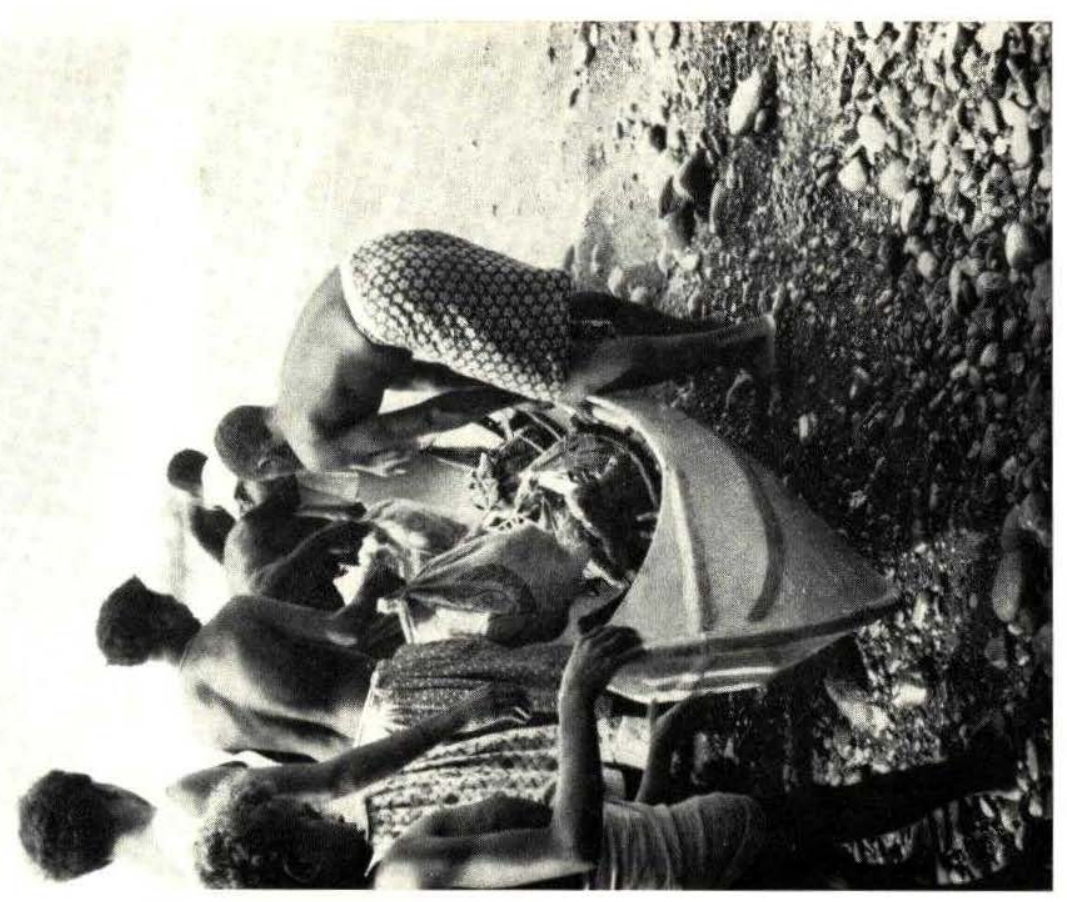

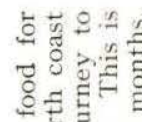

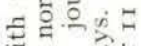

현원

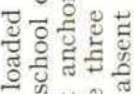

की

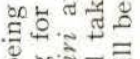

吅 쿷

8 군

สี

노을

- 0 넝

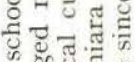

ำ

윰 5

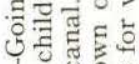

$1=\frac{0}{3} 3$

м.

솝.

S

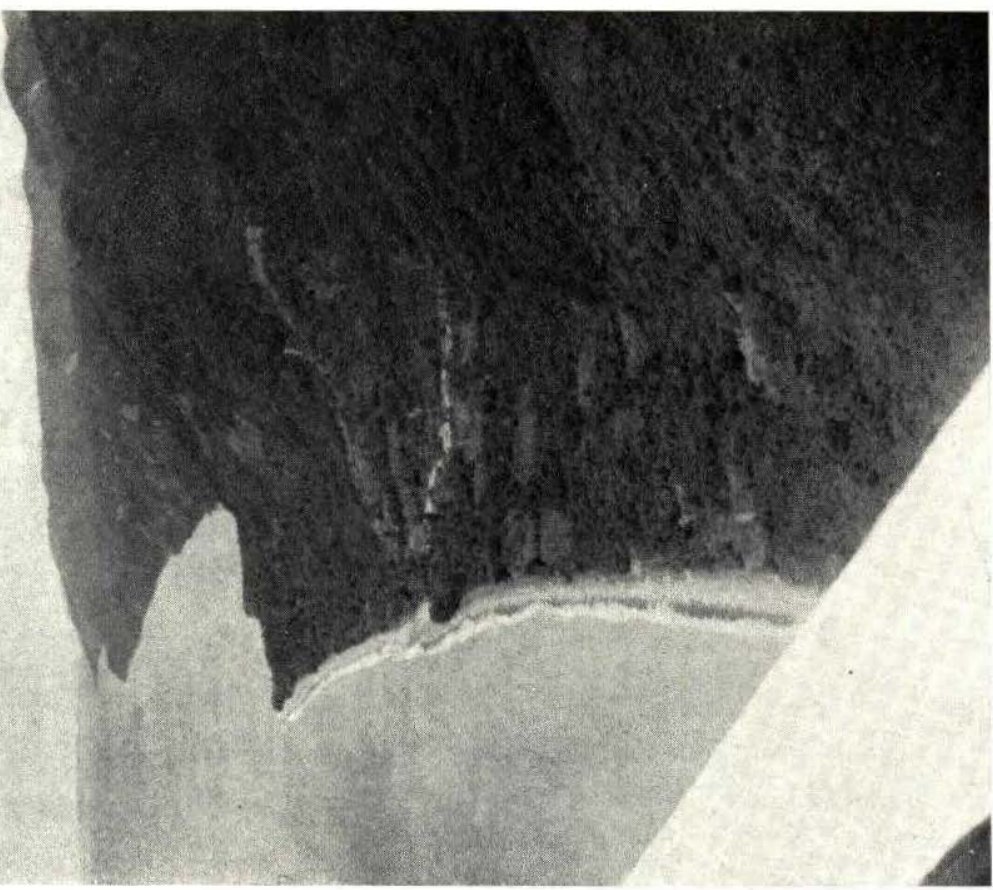

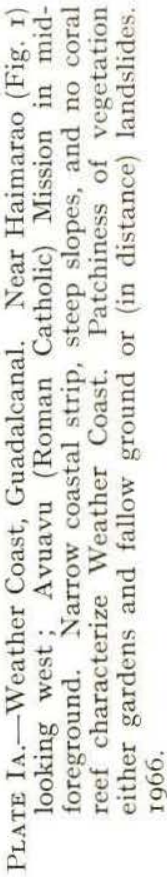


A POPLLATION STLDY IN SOUTH GUADALCANAL : SOME RESLITS AND IMPLICATIONS

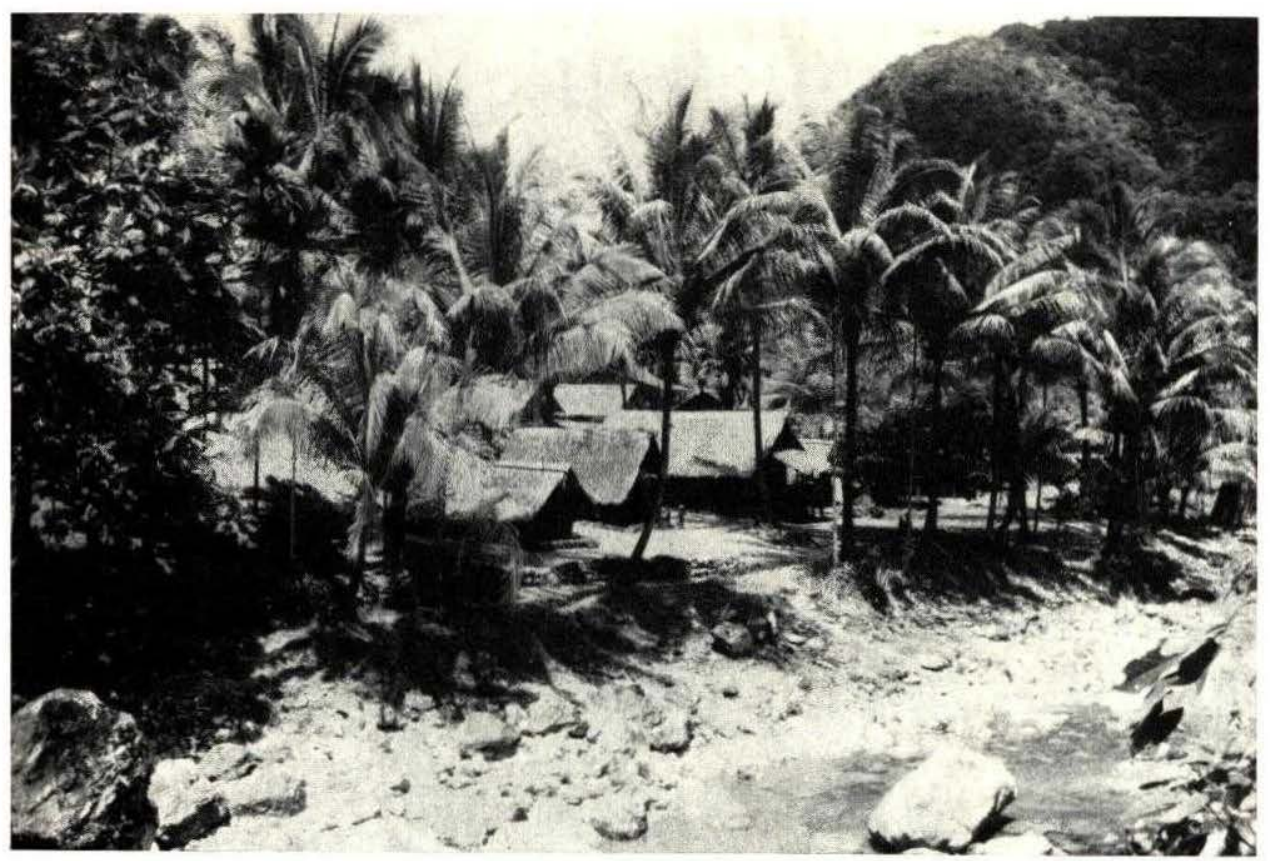

PLATE IIA.-Pichahila Village, looking south-east from west bank of Alualu River. Line of coconut palms make welcome break from enclosing bush. River terraces provide flat site houses are spaced in rows along two lowest terraces. I966.

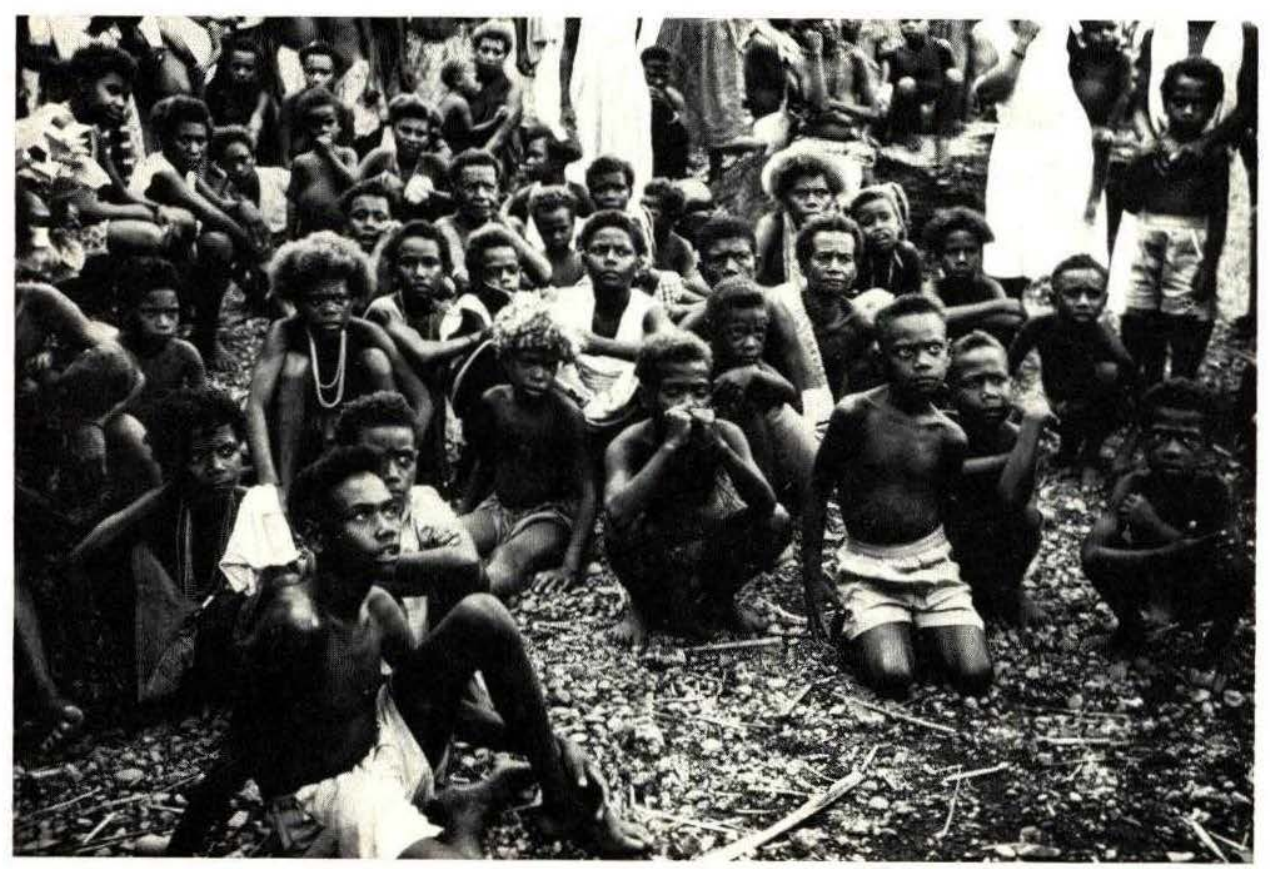

PlAte IIв.-A young population. Audience, mainly Duidui children home for annual holidays, listen intently to "big man's" translation of talk about education. 1965. 
A POPLLATION STUDY IN SOUTH GUADALCANAL : SOME RESULTS AND IMPLICATIONS

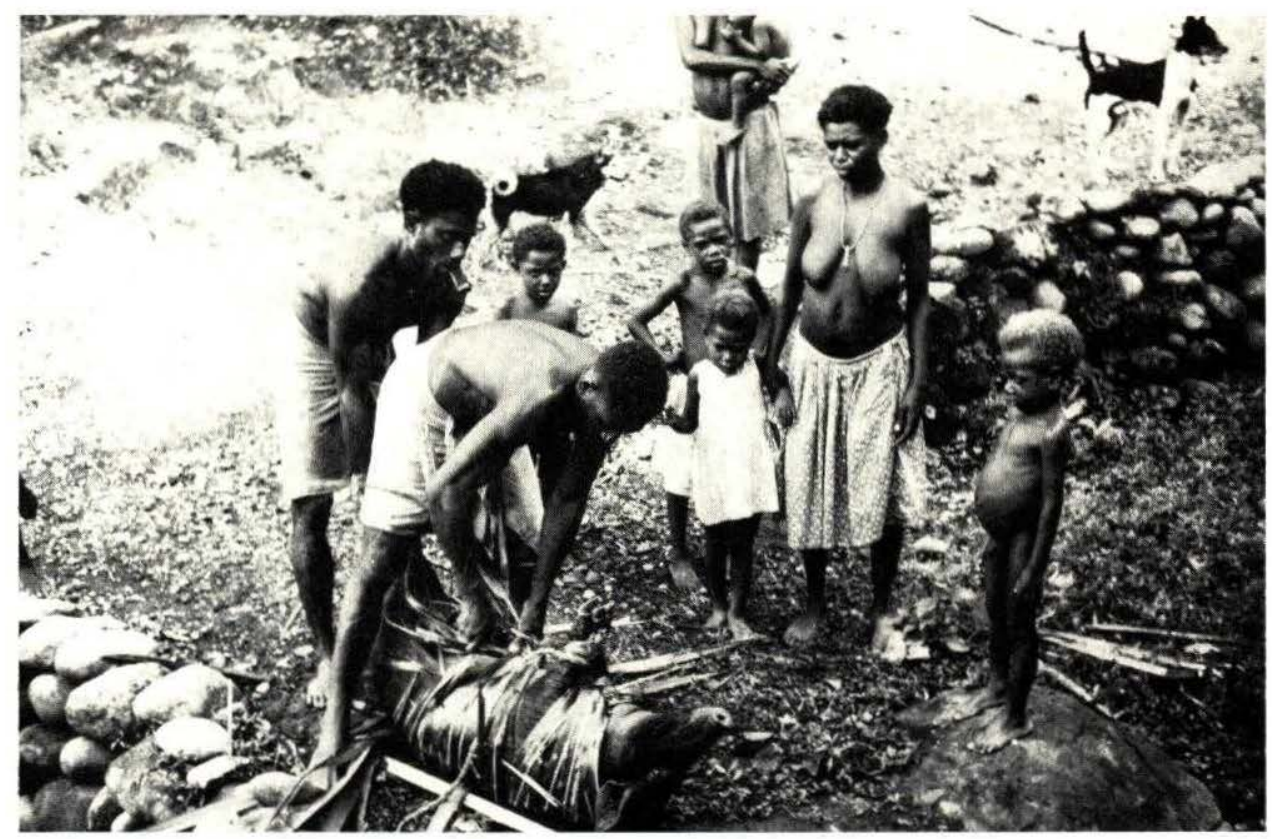

PlATE IIIA.- Journey to sell pig. Mark of Duidui, assisted by Edi, lashes live pig with green leaves to prevent dehydration during three-day voyage by cutter to Honiara. Pig, worth about SA20, to be sold to Malaita man who asked owner to bring it on next visit to town. 1966.

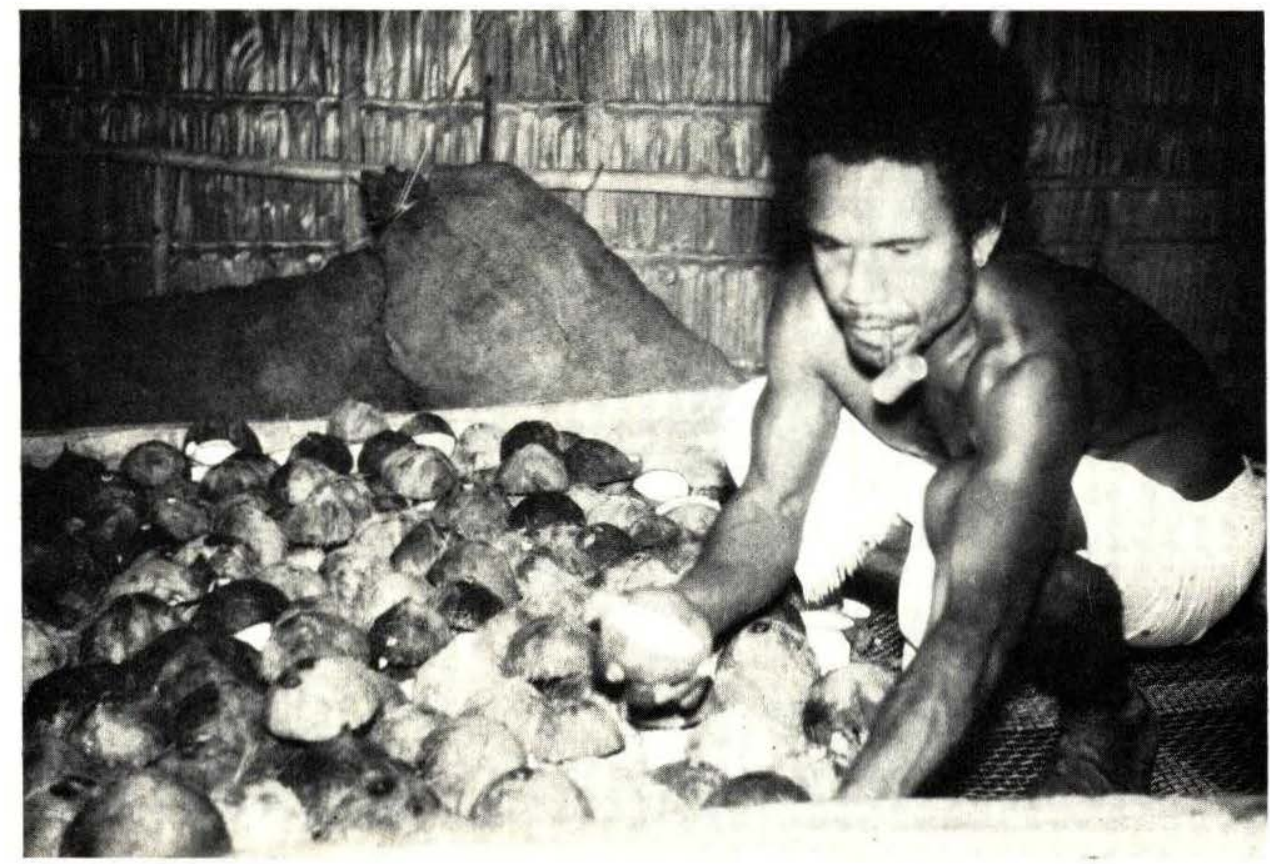

PLATE IIIB.-Local labour, Duidui. Lina, employed by local " big man ", places husked coconut halves on rack of hot-air drier. Most nuts still dried by smoke or spread on beach in hot sun. Dried copra at rear sells for $\$ A 8-12$ per bag in main town. 1967. 


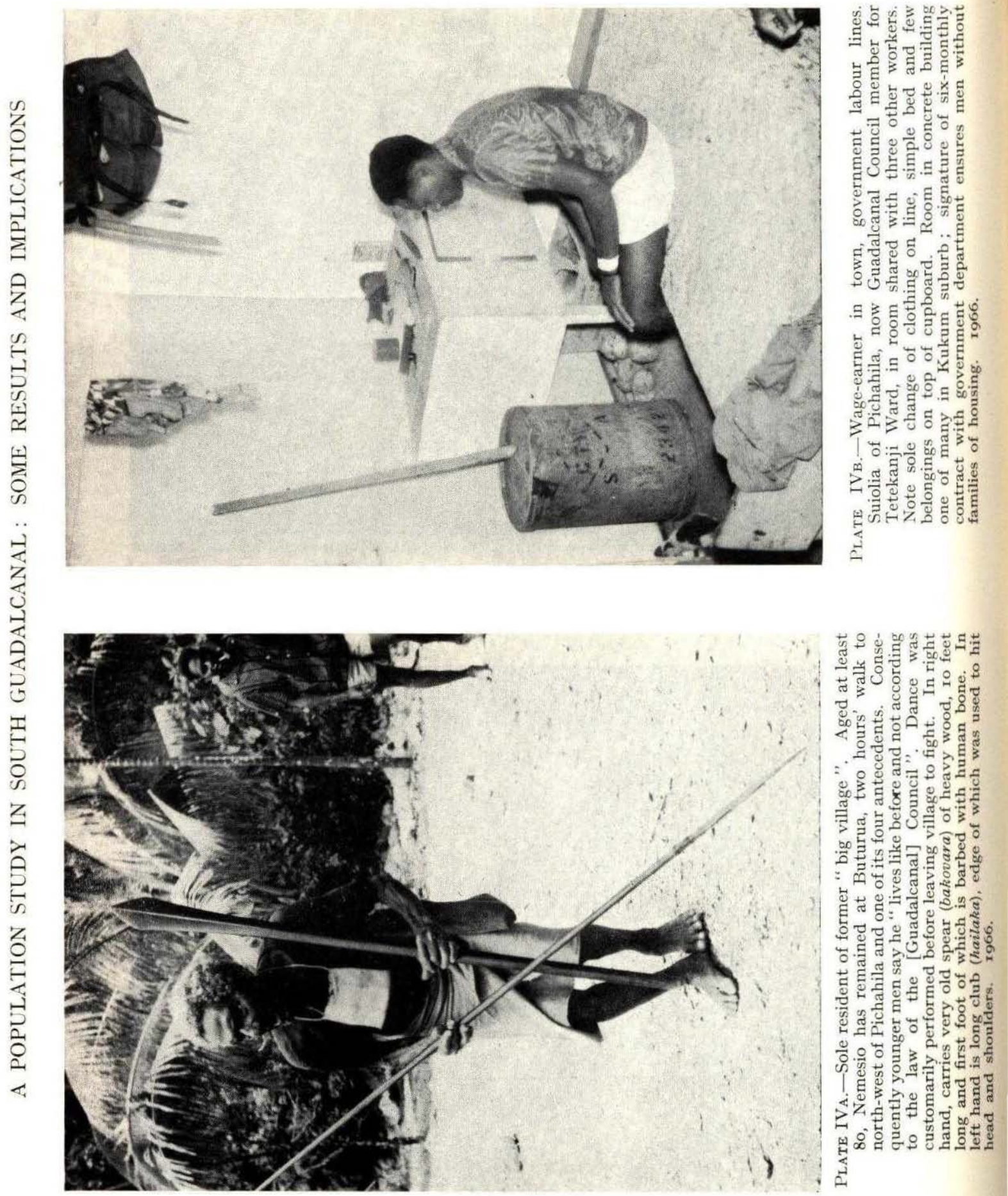


I968 the United Church founded a Youth Training School in the Western Solomons to equip " young people to give useful service in their own villages" ; the year-long course comprises youth leadership, agriculture, home economics, christian education, English, mathematics, woodwork and simple engine maintenance (B.S.I.P.N., I968/8 : 4). Similarly, Mr. Ian Talasasa, Assistant Education Officer for the Central Solomons, recently proposed to the Guadalcanal and Isabel (local government) Councils that a different type of institution be opened for primary school leavers who could not obtain a place in the secondary system. Persons enrolled at this " Bridge School " would receive training in agriculture, carpentry, nursing, engine repair, domestic science and seamanship ; English and civics also were suggested for inclusion. The Isabel Council, at its first meeting for I969, voted to become the first local authority in the Protectorate to establish such a school-hopefully in I970-whilst the Guadalcanal Council still has the plan under discussion (B.S.I.P.N., I968/I2 : II, I969/I : I3 ; C.D.N., I969/I : 2).

It is true that those who proceed beyond the first standards of senior primary school will have to master abstract notions that are increasingly alien to their home environments. Yet this is more a question for the future since only one male from either Duidui or Pichahila has obtained a Senior Primary Certificate. Whilst acknowledging that children attend school for a minimal period of two to three years, the virtually insatiable need at present is the acquisition of some simple skills that are relevant to village livelihood. ${ }^{41}$ Only in this way can formal education be justified as not being a waste of the pupils' time and of their parents' precious money.

As already noted the people in general have a positive attitude towards education. Explained Jason of Duidui, a middle-aged church leader whose two eldest sons have completed Standard V:

When they began school, I had $\$ A 200$ saved. All the money from all the work I had ever done. When they finished school, all my money is spent. All the time they write home asking for money. "Please send money for ink, exercise books, pencils". "I am hungry, father. Please send some money for rice." So now I have no money left. I said : " Now that you are earning money, you have to think the younger ones need schooling. You must help them so they can pull themselves up."

The returns to the village could well be scrutinized more closely in the future, however, particularly since there is likely to be even greater pressure upon the limited cash available locally. This could result, as now occurs in Duidui and has been reported for Malaita (L.C.D., I967/2: I28), in the eldest son being sent to school but not his brothers or sisters, or in a reaction against existing facilities and a co-operative attempt to establish their own. A more critical appraisal of education is not nearly

${ }^{41}$ Discussions subsequent to the 1967 White Paper on Education indicate the administration's increased willingness to recognize this fact: "The need to slant the educational system not only to secondary or tertiary education but also to fit those who wish to return to their villages... is already under study " (Wright, 1969). Such a philosophy was eloquently articulated by Father D. J. Moore, S.M. (1965, I968a, 1968b), throughout his 30 years in the Protectorate. 
as unlikely as might appear. One man suggested to the I966 meeting of the Guadalcanal Council, held on the Weather Coast, that no fees be paid for the Standards I and II offered by village schools, because the children " no learn much" and their teachers "no savvy" [do not know anything].

The more efficient utilization of the physical and human resources of the Solomons is not likely to be attained until the majority of the people possess a wider range of manual skills, a greater awareness of nutrition and health care, the beginnings of a meaningful literacy, and a more than embryonic extra-community awareness. A similar concern prompted Bishop Leonard Alufurai to declare at the June, 1965, meeting of the Legislative Council :

People, society and education should go very close together. There should now be a deliberate effort to integrate learning with the needs of society because unless we do this, education in the Solomons is going to sink into a self-validating routine irrelevance (L.C.D., I965/I: 4I-42).

\section{Overview}

"Observations made and information received", noted one administrator in I963, " indicate that people in the pilot project areas moved from place to place for economic, social and administrative reasons. This is not a major feature, however."

It is understandable that a field officer, directed to inform residents why their leaf houses were being sprayed to combat malaria, should underestimate the full significance of their mobility. This is the predominant means by which they earn cash, a practice that dates from the 187 os but one in which more local sources of work gradually are replacing the once-favoured distant plantation. By going "walkabout ", especially to Honiara, the people observe the "white man's world ", since very few Europeans stay overnight in a Weather Coast village and those administrators or missionaries who do can hardly be said to represent the full range of alternatives that Euro-American society has to offer. If any person from either Duidui or Pichahila wishes to attend a primary school, obtain vocational training, visit a fully equipped hospital, even post a letter or open a bank account, then he must move out of the community to the location of such facilities. In no case will this involve a walk of less than two hours ; in many instances it will require a boat journey of two and a half days (Plates Iв and IIIA).

Comments Proctor (1967b: $\mathrm{I}$ ), on the basis of experience with the community education project at Makaruka and nearby Balo: "Sometimes different people attend classes as there is much movement in and out of the village... The response ... therefore does not alter because of lack of interest on the part of the regular 'scholars', but only because it is either expedient for them to leave the village or because they have a more pressing engagement elsewhere." Throughout the Solomons single men move to evade local taxes and migrant wage-labour transmits malaria from islands like Malaita, where it is endemic, to those such as Guadalcanal, 
where it is not any longer ; conversely, skilled tradesmen are unable to be lured from their homes by the conventional rewards of higher pay, productivity bonuses or long-service pensions.

In this situation the administrator cannot automatically assume all Solomon Islanders not somewhere at paid employment to be resident in their own village. The evolution of policy must therefore reflect any changes in the rate, direction, seasonality, and predominant reasons for the people's constant ebb and flow, not to mention which segments of the community are most mobile and which are not. The use for this kind of information, as the first results from this study suggest, varies from such mundane matters as the availability of carriers for touring officers to more fundamental questions like the formulation and siting of a community development scheme.

\section{ACKNOWLEDGEMENTS}

The field study on Guadalcanal's Weather Coast was funded by an International Development Fellowship from the East-West Center, Honolulu; archival research in Fiji, the drafting of the figures, and the publication of the plates, by small grants from the South Pacific Commission, the East-West Center, and the University of Hawaii respectively. The original report to the Western Pacific High Commission, upon which this paper is based, was written whilst holding a Graduate School Fellowship at the University of Washington, and its revision undertaken during a study award in demography from the Ford Foundation and the International Population Program, Cornell University.

Within the Solomons, special thanks are due to Mr. and Mrs. James Tedder and Mr. and Mrs. Robin Plummer, Honiara, for unstinting help in matters both personal and academic ; to Fathers John Giesselink, Cornelius Hooÿmeÿers (Avuavu Mission), William van Duin and John (Makina Mission) for their generous hospitality. The debt to my hard-worked interpreters (Sandy of Duidui and Gabriel Saisudnana of Vatualae), to two outstanding "big men" (District Headman Marcus Pipisi and Assistant District Headman Petero Cheni), and to the ever-courteous people of Duidui and Pichahila, is incalculable.

For on-the-spot evaluations of the original report, my thanks to Bishop John of Melanesia and Messrs. Francis Bugotu, B. D. Hackman, D. H. Hibbert, N. ScottElliot, William A. Wright and B. C. Wilmot; comments by Drs. A. M. Healy, Wollongong University College; H. I. Hogbin, University of Sydney; and I. Q. Lasaqa, University of the South Pacific, also have aided the subsequent revision. The meticulous maps were drawn by Mr. Karl Johansen, University of Washington.

\section{BIBLIOGRAPHY}

Allan, C. H. (1957) : Customary Land Tenure in the British Solomon Islands Protectorate, Report of the Special Lands Commission, Honiara, Western Pacific High Commission.

Barrau, J. (I958) : "Subsistence Agriculture in Melanesia ", Bernice P. Bishop Museum Bulletin No. 2 I9, Honolulu. 
Bellam, M. E. P. (1963): The Melanesian in Town : A Preliminary Study of Adult Male Melanesians in Honiara, British Solomon Islands, unpublished M.A. thesis, Victoria University of Wellington.

Belshaw, C. (1963): "Pacific Island Towns and the Theory of Growth", in Pacific Port Towns and Cities: A Symposium, A. Spoehr (Ed.), Honolulu, Bishop Museum Press, pp. 17-24.

B.S.I.P. (1960) : Journey Through the Ground and Other Stories from the Solomon Islands, Honiara, Department of Education.

B.S.I.P. (1962a) : Educational Policy, White Paper No. 3, Honiara.

B.S.I.P. (1962b): The Respective Functions of Local Councils and Central Government, White No. 2, Honiara.

B.S.I.P. (1965) : Honiara Census 1965 : Instructions to Enumerators, Honiara.

B.S.I.P. (r966a) : Careers for Solomon Islanders, Honiara, Department of Education.

B.S.I.P. (1966b) : Labour Department: Annual Report for the Year Ended 31st December, 1965 , Honiara.

B.S.I.P. (1967) : Educational Policy, White Paper No. 11, Honiara.

B.S.I.P. (n.d. [? r968]): Syllabus for Junior Primary Schools, Honiara, Department of Education.

B.S.I.P. (n.d.): Solomon Islands Stories, Honiara, Information Office.

B.S.I.P. Legislative Council Debates (1964-67): Official Report, Honiara (bi-annual).

B.S.I.P. News Sheet (1966-69), Honiara, Information Service (bi-monthly).

Brown, P., and Winefield, G. (I965): "Some Demographic Measures Applied to Chimbu Census and Field Data", Oceania, Vol. XXXV, pp. 175-90.

de Bruijn, J. V. (I963) : "Urbanization in the South Pacific", South Pacific Bulletin, Vol. I3. pp. $20-4,66-67$.

Bugotu, F. (1968): “" The Culture Clash: A Melanesian's View”, New Guinea, Vol. 3, pp. 65-70.

Capell, A. (r93o): "The Language of Inakona, Guadalcanal, Solomon Islands", Journal of the Polynesian Society, Vol. 39, pp. $113-136$.

Capell, A. (1962): A Linguistic Survey of the South-Western Pacific, Technical Paper No. I36, South Pacific Commission, Noumea.

Central District News (1968-69), Honiara, District Administration, Central Solomons (monthly).

Chapman, M. (1967): "Population Research in the Pacific Islands: A Case Study and Some Reflections ", paper prepared for the East-West Center Conference on Population Studies, Honolulu, July II-I3. Mimeographed.

Charles, E., and Forde, C. D. (1938) : "Notes on Some Population Data from a Southern Nigerian Village", Sociological Review, Vol. XXX, pp. I45-160.

Cochrane, D. G. (in press): "Development Administration and Applied Anthropology ", Human Organization.

Davenport, W. (r968) : "Social Organization Notes on the Southern Santa Cruz Islands: Utupua and Vanikoro", Baessler-Archiv (n.s.), Vol. XVI, pp. 207-275.

Davenport, W., and Çoker, G. (1967): "The Moro Movement of Guadalcanal, British Solomon Islands Protectorate", Journal of the Polynesian Society, Vol. 76, pp. 123-175.

Epstein, A. L., and T. S. (1962): "A Note on Population in Two Tolai Settlements", Journal of the Polynesian Society, Vol. 71, pp. 70-82.

Firth, R. (1955): "Census and Sociology in a Primitive Island Community (Tikopia)", in Proceedings of the World Population Conference, 1954, Vol. VI, New York, United Nations, PP. II 7 - I25.

Fortes, M. (1954): "A Demographic Field Study in Ashanti", in Culture and Human Fertility : A Study of the Relation of Cultural Conditions to Fertility in Non-Industrial and Transitional Societies, Paris, UNESCO, pp. 253-339.

The Forum (I968), Honiara, Department of Education, Central District (quarterly).

Groenewegen, K. ( 1967 ) : “Demographic Data for Selected Areas of Western New Guinea, 1960-62", Pacific Viewpoint, Vol. 8, pp. 87-91.

Grover, J. C. (1957) : " Some Geographical Aspects of the British Solomon Islands in the Western Pacific", Geographical Journal, Vol. CXXIII, pp. 298-317.

Grover, J. C. (1965): " River Control to Avert Threat to Avu Avu Mission, South Guadalcanal ", in The British Solomon Islands Geological Record, 1959-62, Vol. II, Honiara, Western Pacific High Commission, pp. 212-213.

Hackman, B. D. (1968): A Guide to the Spelling and Pronunciation of Place Names in the British Solomon Islands Protectorate, produced under the auspices of the Geographical Names Committee, Honiara, Lands and Surveys Department, B.S.I.P.

Hibbert, D. H. (1968): Personal communication, 6th February.

Hogbin, H. I. (r937): "The Hill People of North-Eastern Guadalcanal ", Oceania, Vol. VIII, pp. $62-89$.

Hogbin, H. I. (r938) : "Social Organization of Guadalcanal and Florida, Solomon Islands", Oceania, Vol. VIII, pp. 398-402. 
Hughes, A. V. (r969) : " Low-cost Housing and Home Ownership in Honiara, British Solomon Islands Protectorate", South Pacific Bulletin, Vol. 19, pp. 19-26.

Larson, E. H. (1968): "Tikopian Labour Migration to the Russell Islands ", Journal of the Polynesian Society, Vol. 77, pp. 163-176.

Lasaqa, I. Q. (1968) : Melanesians' Choice: A Geographical Study of Tasimboko Participation in the Cash Economy, Guadalcanal, British Solomon Islands, unpublished Ph.D. thesis, Australian National University.

Lowen, J. (1967a) : "Report of Adult Education Experiment (Makaruka, Weather Coast)", report prepared for the District Administration, Central Solomons, Honiara. Mimeographed.

Lowen, J. (1967b) : "Statistics and Suggestions Concerning the Community Education Projects [at Makaruka and Balo] ", report prepared for the District Administration, Central Solomons, Honiara. Typescript.

Macgregor, J. D. (I968): “ Demographic Aspects of Malaria Eradication ”, report prepared for the B.S.I.P. Malaria Advisory Committee, Honiara. Typescript.

McArthur, N. (I96r) : Report on the Population Census of 1959 [British Solomon Islands Protectorate], Honiara, Western Pacific High Commission.

McArthur, N. (I966): "The Demographic Situation", in New Guinea on the Threshold, E. K. Fisk (Ed.), Canberra, Australian National University Press, pp. ro3-1r4.

Moore, Father D. J. (1965) : Catholic Education, South Solomons, 1965, Honiara, Catholic Mission.

Moore, Father D. J. (I968a): "Farewell Address", B.S.I.P. News Sheet, No. 3, pp. 4-7.

Moore, Father D. J. (I968b) : "Localisation", The Forum (Department of Education, Central District), No. 3, pp. $24-26$.

Miura, Y. (1967): "A Comparative Analysis of Operational Definitions of the Economically Active Population in African and Asian Statistics ", in Proceedings of the World Population Conference, I965, Vol. IV, New York, United Nations : Department of Economic and Social Affairs, pp. $372-379$.

O'Connor, G. C. (I969): The Moro Movement of Guadalcanal, unpublished Ph.D. thesis, University of Pennsylvania.

Proctor, J. (I967a) : "Community Education Project in Makaruka", report prepared for the District Administration, Central Solomons, Honiara. Mimeographed.

Proctor, J. $(1967 b)$ : "Comparative Account of the Community Education Projects in the Villages of Makaruka and Balo", report prepared for the District Administration, Central Solomons, Honiara. Typescript.

Rennie, J. S. (1962) : "The Relationship between the Research Worker and the Administration" in Urbanization in the South Pacific, Technical Paper No. 137. South Pacific Commission, Noumea, pp. I4-18,

Russell, T., et al. (1958) : Report of the Committee Appointed to Consider the Housing of Solomon Islanders in Honiara, Honiara. Mimeographed.

Scott-Elliot, N. (1967): Personal communication, 3ist December.

Scragg, R. F. R. (1967): " Mortality Decline in a Sample Population in New Guinea ", in Contributed Papers, Sydney Conference, International Union for the Scientific Study of Population, 2 Ist $-25^{\text {th }}$ August, pp. 562-572.

Solomon Islands Broadcasting Service (1966): "Tuesday Talk", panel discussion by Miss Lily Ogatina and the Hons. Mariano Kelesi, E. V. Lawson and T. Russell on the B.S.I.P. Legislative Council's Seventh Session, Second Meeting, 3oth November-r $4^{\text {th }}$ December. Transcribed from tape.

Tedder, J. L. O. (I966) : "Honiara, Capital of the British Solomon Islands Protectorate", South Pacific Bulletin, Vol. I6, pp. 36-4I, 43.

Tedder, J. L. O. (1967): Personal communication, 6th April.

Veronica, Sister (r955): "The Destruction of Tangarare Mission in the Great Cyclone of January, 1952", Transactions British Solomon Islands Society, Vol. II, pp. I-3.

Wilmot, B. C. (1967): Personal communication, 27th December.

Winkler, H. A. (1968): Report on Copper Prospects of the Koloula River Granodiorite, Honiara, Department of Geological Surveys, B.S.I.P.

Wright, L. W. S. (r938) : "Notes on the Hill People of North-Eastern Guadalcanal ", Oceania, Vol. IX, pp. 97-roo.

Wright, W. A. (1969): Personal communication, 18th February.

Wrightson, J. R. (1953) : “ A Demographic Survey of the Talise Sub-District of South Guadalcanal ", typescript held by Central Archives for Fiji and the Western Pacific High Commission, Suva.

Murray Chapman. 